\title{
Migrations in the Archaeology of Eastern and Southeastern Europe in the Early Middle Ages (Some Comments on the Current State of Research)
}

\author{
Florin Curta
}

Historians of the modern era have recently turned Eastern Europe into a vagina nationum: the greatest mass migration and even the "making of the free world" are directly related to Eastern Europe. ${ }^{1}$ Historians studying Late Antiquity and the early Middle Ages disagree. They doubt that migration could explain even changes taking place in the region. Walter Goffart sees no reason for Germanic tribes residing in the vastness of Ukraine to emigrate: "if really land hungry, they might have satisfied their needs right where they were". ${ }^{2}$ According to Guy Halsall, the archaeological record pertaining to East Central Europe in the 3 rd century does "not support the idea of a substantial migration". ${ }^{3}$ Instead, one can envision communication lines along the principal trade routes. ${ }^{4}$ The idea that the Goths migrated out of northern Europe to the fringes of the Empire rests "mainly on the evidence of a single ancient source, the Getica of Jordanes, around which complicated structures of scholarly hypothesis have been built". ${ }^{5}$ One could argue in principle that the Sântana de MureşČernjachov culture came into being "because of a migration out of the Wielbark regions, but one might equally argue that it was an indigenous development of local Pontic, Carpic, and Dacian cultures". 6

Peter Heather, however, is skeptical about skepticism. To him, there can be no doubt that the Wielbark people morphed into the Sântana de MureşČernjachov people, who became Goths in the course of a century-long migration across Eastern Europe, from the Baltic to the Black Sea. ${ }^{7}$ Similarly, the

\footnotetext{
Zahra, Great Departure. Vagina nationum:Jordanes, Getica 25, ed. Mommsen, p. 6o, lines 5-6.

Goffart, Barbarian Tides, p. 29.

Halsall, Barbarian Migrations, p. 133.

4 Halsall, Barbarian Migrations, p. 421.

5 Kulikowski, Rome's Gothic Wars, p. 41.

6 Kulikowski, Rome's Gothic Wars, p. 67.

7 Heather, Goths, p. 43.
} 
Slavic migration is traceable by means of a "thin' ribbon of Korchak sites". The Slavs "spread into the power vacuum created by Przeworsk culture collapse in the late fifth or the earlier 6th century". ${ }^{8}$ The lack of archaeological evidence in support of such a model of early medieval migration is gleefully dismissed: "the range of evidence available for the nature and scale of Slavic migration flows bears not the remotest resemblance to anything you might consider an ideal data set; but this is all part of the fun of early medieval history". ${ }^{9}$ With his mind set on fun activities, Heather offers an analogy for the migration process that he envisioned: "billiard balls rolling around the green baize table. Something might make the balls roll from one part of the table to another-overpopulation at the point of departure was the usual suspect - but any one ball was straightforwardly the same ball in a different place when the movement had finished". ${ }^{0}$

Goffart and Kulikowski are right to point out that a text-hindered archaeology will never effectively contribute to the debate surrounding migration. Heather is also right about the use of anthropological models of migration to understand early medieval migrations: mobility is not a modern phenomenon and "cultural mobility is a key constituent element of human life in virtually all periods" of history. ${ }^{11}$ However, none of them is either aware of the existence in Eastern Europe of a large body of literature on early medieval migrations, or indeed familiar with the abundant archaeological literature pertaining to it. For example, Peter Heather's billiard analogy shows ignorance of, and is in direct contradiction with László Vajda's 40-year old study of "chain migration". Vajda has demonstrated that the idea of billiard-like, chain migrations was directly borrowed from Herodotus. This idea was the result of a deductiverationalistic mode of thinking epitomized by classical mechanics, with its emphasis on point particles. ${ }^{12}$ In other words, the description in historical sources of movements of population as billiard balls is nothing but a metaphor (and a

8 Heather, Empires and Barbarians, pp. 410-411. See also ibid., p. 437: "Slavic migration generated the recolonization of the lands left empty by Germanic migrants of the Völkerwanderung era".

9 Heather, Empires and Barbarians, p. 427.

10 Heather, Empires and Barbarians, p. 11.

11 Dommelen, “Movins on", p. 480.

12 Vajda, "Zur Frage", p. 35. Vajda reacted against the use of "chain migration" in ethnology and sociology, for which see, for example, Macdonald/Macdonald, "Chain migration". The concept is still used by some historians in Eastern Europe, who, like Heather, ignore Vajda's work (e.g., Pylypchuk, "Predystoriia vengrov"). 
way to display knowledge of the classics), not a description of what has actually happened. Similarly, Peter Heather's pondering whether the wave of advance model fits the Slavic migration obviously ignores Evžen Neustupnýs remarks on the migrations as infiltrations. ${ }^{13}$ According to the Czech archaeologist, the migration of the Slavs "could have taken the most varied forms including colonization, expansion, invasion, and infiltration either at the same time or in some sort of sequence". ${ }^{14}$ No participant in the current debate surrounding migrations seems to be aware of the discussions on this topic that took place in 1970 s and 1980 s in Soviet archaeology. Soviet archaeologist traced migrations in Eastern Europe to the historical dialectics of modes of production, and, drawing on Marxist theory, conceptualized them from theoretical platforms such as economic primitivism, environmentalism, and imperialism. ${ }^{15}$ Migration was described in rich conceptual terms, even though models of historical migrations did not really fit the archaeological evidence. Lev Klein's recent survey of those discussions is also a plea: migrations, according to him, can be recognized archaeologically and even distinguished in their different manifestations - migration of an entire population, migration of a specific group, or forced movement of population (deportation). ${ }^{16}$

Such optimism is also responsible for the recent enthusiasm on display in the application of bioarchaeology for tracking migrations in Eastern Europe. Molecular anthropology, for example, has the ability to distinguish similarities in the noncoding regions of the genome, which can reflect shared ancestry and/or the exchange of genes via the movement of individuals between populations. Some scholars compare contemporaneous populations from different geographic regions. If similarity is detected, then they draw the necessary conclusion that those populations share ancestry, which in turn may imply migration. Such was the idea behind a recent study of paternal genetic lineages, looking for the subclade Rib-M73 in several modern populations- the Kazakh, the Karakalpak, and the Bashkir Kipchaks. Their common ancestors are believed to have been the medieval Cumans. ${ }^{17}$ Other scholars choose to compare

13 Heather, Empires and Barbarians, p. 422. Nonetheless, Heather's "Slavic spread" is a copy of Lucien Musset's "avance slave". See Musset, Les invasions, pp. 87-92; Heather, Empires and Barbarians, pp. 419-420.

14 Neustupný, "Prehistoric migrations”, p. 287. For Neustupnýs ideas, see Kuna, "Intransigent archaeology”; Kristiansen/Šmejda/Turek, "Evžen Neustupný".

15 Frachetti, "Migration concepts", p. 198.

16 Klein, "Migraciia", p. 67. For Klein's ideas, see Leach, Russian Perspective.

17 Volkov, "K voprosu o migraciiakh". The attribution of the subclade to Cuman ancestry is based on its distribution, which is believed to coincide with the territory that the Cumans controlled between the $9^{\text {th }}$ and the 13th centuries (ibid., p. 302 fig. 4). 
populations that inhabited the same geographic region at different points in time. In this case, similarity reflects genetic continuity, while differences betray immigration, or even population replacement. ${ }^{18}$ Mitochondrial genome sequences thus show a continuity of several maternal lineages in Central Europe from the Bronze and Iron Ages. That excludes the possibility that in Late Antiquity, the northern areas of Central Europe were depopulated through the emigration of the Goths, only to be repopulated by Slavic immigrants in the 6th century. ${ }^{19}$ The comparison of contemporaneous, Slavic-speaking populations in Eastern Europe, however, led to a radically different conclusion: only migration could explain the genetic similarity between populations in the Balkans and in East Central Europe. ${ }^{20}$

Biogeochemical techniques have also been used for the identification of first-generation immigrants. Biogeochemical values are compared for dental and skeletal elements that formed at different times over an individual's lifetime. If those values are different for dental and skeletal elements, then the individual in question must have moved from one geologic or environmental zone to another during his or her lifetime. ${ }^{21}$ The strontium isotope analysis of 13 out of 49 skeletons from the Viking-age cemetery in Bodzia (Poland) has revealed that only one individual was of local origin. Although the analysis could not point to the origin of the "foreigners", "the archaeological context implicate Kievan Rus' very strongly, and the isotopic evidence from strontium fits that interpretation". ${ }^{22}$ Similar conclusions have resulted from the isotope analysis

18 Bolnick, "Continuity and change", pp. 265-266.

19 Mielnik-Sikorska et al., "The history of the Slavs".

20 Malyarchuk et al., "Mitochondrial DNA variability". It is of course impossible to date that migration, which could may very well have taken place long before the Middle Ages. For a similar conclusion based on non-recombining Y chromosome from 25 extant populations of Europe and the Middle East, see Šlaus et al., "Craniometric relationships", p. 441.

Tütken/Knipper/Alt, "Mobilität und Migration"; Schweissing, "Archäologische Fragen”; Knudson, "Identifying archaeological human migration", p. 232. The underlying idea of such techniques of analysis is that, during an individual's life development, strontium substitutes for calcium in hydroxyapatite, the mineral component of enamel and bone. Enamel (on the permanent teeth) is formed in early childhood and does not change through life. It is also the hardest tissue in the skeleton and therefore resistant to decay and diagenesis. The ratio of the radiogenic isotope of strontium, ${ }^{87} \mathrm{Sr}$, and one stable isotope of strontium, ${ }^{86} \mathrm{Sr}$, found in the teeth and in the bones reflect the ${ }^{87} \mathrm{Sr} /{ }^{86} \mathrm{Sr}$ found in plants, animals, and water that the individual in question consumed during his or her lifetime. That in turn reflects the isotope ratios found in the soil and bedrock of the specific region in which the individual lived. If the isotopic ratios of the place of burial are different from those of the enamel, then the individual in question must be a migrant, who changed residence during his or her lifetime.

Price/Frei, "Isotopic proveniencing", pp. $457-45^{8}$ and 462. 
of tooth enamel from skeletal material found in the 6th-century cemeteries of Lužice and Holubice (Czech Republic). There were many immigrants among those buried in those cemeteries, each one of which was in use over three successive generations. ${ }^{23}$ Sometimes, however, the strontium isotope analysis may produce different results. Only five out 17 skeletons in the $5^{\text {th- }}$ to 9 thcentury cemetery located to the south from the late Roman fort in KeszthelyFenékpuszta (Hungary) were of immigrants, but they were all buried in exactly the same manner and style as the locals. ${ }^{24}$

Southeastern Europe is perhaps the only part of the Continent in which migrations have been concocted out of thin air, against all evidence produced by archaeology. The presumed ancestors of the Albanians, the Bessi, are said to have lived in the lands on both sides of the present-day Bulgarian-Serbian and Bulgarian-Macedonian borders. At some point during the first half of the gth century, they were pushed out of their ancestral lands by the Byzantine-Bulgar wars, and they moved to the west, where they became Albanians. ${ }^{25}$ While there is plenty of evidence for an out-migration of Albanians in the 14th century, primarily because of the profound transformations taking place in the tribal society, and the concomitant rise of the Albanian aristocracy, there is absolutely no archaeological evidence of a 9th-century migration from western Bulgaria to Albania-of Bessi, proto-Albanians, or of anyone else. ${ }^{26}$ Romanians are also said to have come to the present-day territory of their country in waves over several centuries, some as late as the 13th or 14th centuries. ${ }^{27}$ This has often been regarded as a form of return migration, since the Latin-speaking population of the province of Dacia was also believed to have migrated to the Balkan Peninsula after the abandonment of the province in the late 3 rd century. The migration out of Dacia supposedly took place in the early $7_{\text {th }}$ century, when the Danube frontier of the Empire presumably collapsed under the pressure of the Avars and Slavs. Place names of Latin origin, the existence of Vlach communities in the Balkans, as well as the close relations between their dialects and the Romanian language have all been treated as sufficient evidence for the later migration of Romanians back to the same

\footnotetext{
23 Tejral, “K současnému stavu”, p. 59.

24 Heinrich-Tamáska/Schweissing, "Strontiumisotopen- und Radiokarbonuntersuchungen", pp. 466-467. No more than a quarter of the entire population buried in KeszthelyFenékpuszta is made up of "foreigners".

25 Schramm, Anfänge, pp. 149-156.

26 Ducellier, "Les Albanais".

27 Friedwagner, "Über die Sprache und Heimat", p. 692; Darkó, "Die Übersiedlung der Walachen”; Stadtmüller 1950, 207 with 205 map 12.
} 
lands abandoned by their ancestors in the early 7 th century. ${ }^{28}$ There are serious problems with such interpretations of the primarily linguistic evidence, not the least of which is the inability to date any phonetic and/or linguistic changes with sufficient precision for the historical reconstruction. More recent archaeological research has painted a very bleak picture of the Balkans in the $7^{\text {th }}$ century, one of largely uninhabited areas in the center of the Peninsula, precisely those areas to which the immigrants from present-day Romania is said to have moved after the collapse of the Danube frontier. ${ }^{29}$

Moreover, early medieval migrations to and from the Balkans are well documented, but none of them fits the idea of a Romanian migration to Romania. For example, the fifth miracle in Book II of the Miracles of St. Demetrius contains the story of the Sermesianoi-the descendants of prisoners that the Avars had taken from the Balkan provinces in the early 7 th century, and had then moved forcefully to Pannonia, in the area of Sirmium (hence their name). After 60 years, during which they were ruled by their own chieftains, the Sermesianoi rose in rebellion against the Avars, and migrated across the Danube back into the Balkans. ${ }^{30}$ In the early gth century, after Krum's successful campaigns in Thrace, between 10,000 and 20,000 prisoners of war are said to have been forcefully moved to "Bulgaria beyond the Danube", which was most likely located in southern Romania. Much like the Sermesianoi, those prisoners had their own leaders. With the assistance of the Byzantine fleet on the Danube, after spending 40 or 50 years in "Bulgaria beyond the Danube", the Adrianopolitans rose in rebellion against the Bulgars, and migrated back to their homeland inside the Empire. ${ }^{31}$

28 Schramm, Eroberer und Eingesessene, pp. 131-140. Stanev, "Migraciiata ot Trakiia”, pp. 214217 believes that the Vlachs of Epirus, Thessaly, southern Macedonia, and Albania migrated to northern Bulgaria under the pressure of the Normans at the end of the 11th century and in the early 12 th century.

29 Curta, "The beginning of the Middle Ages".

$30 \quad$ Miracles of St. Demetrius II 5, in Lemerle, Les plus anciens, pp. 286-288; Pillon, "L'exode des Sermésiens", pp. 104-105. Werner, Der Schatzfund von Vrap, and "Der Schatz eines awarischen Kagans" has unsuccessfully tried to link this migration to the hoard of silver vessels and belt fittings from Vrap (Albania). For the hoard, see now Garam, "The Vrap treasure" and Piguet-Panayotova, "The gold and silver vessels".

31 Scriptor incertus, ed. Iadevaia, pp. 54-55; Tăpkova-Zaimova, "Migrations frontalières", pp. 126-127. For "Bulgaria beyond the Danube" and its administrative organization, see Brătianu, "Bulgaria de dincolo de Dunăre"; Tăpkova-Zaimova, "Roliata i administrativnata organizaciia". Several cemeteries in Walachia, the stronghold in Slon, and a number of hoards of iron implements and weapons have been linked to "Bulgaria beyond the Danube" (Fiedler, "Bulgars in the Lower Danube region", pp. 155-156; Ciupercă, "Some observations"; Canache/Curta, "Depozite de unelte şi arme medievale timpurii"). 
With no such accounts at their disposal, archaeologists have long debated the origins of the 4th- to 7 th-century archaeological culture in the Samara Bend known as Imen'kovo, after the eponymous site at the confluence of the Volga and the Kama rivers. ${ }^{32}$ According to Galina Matveeva, that culture originated in the Zarubyntsi culture of western Ukraine (3rd century B.C. to 1st century A.D.). ${ }^{33}$ Her critics pointed out that in Late Antiquity and the early Middle Ages, migrations were usually from the east to the west, not the other way around. Others notes that 400 years separated the end of the Zarubyntsi from the beginning of the Imen'kovo culture. Nonetheless, the idea of a western origin of the Imen'kovo culture was the orthodoxy during the first decade of the 21st century, even though the exact identity of the migrants (or, later, of the bearers of the Imen'kovo culture) remained a matter of dispute. Valentin Sedov believed that the origins of the Imen'kovo culture must be sought in the Sântana de Mureş-Chernyakhov culture, which was at that same time at the center of the debate surrounding the early history of the Goths. The Imen'kovo people later migrated to Left-Bank Ukraine, where they laid the foundations of the Volintsevo culture of the 8th- to the 1oth-century Slavs on the northern border of Khazaria. ${ }^{34}$ Others denied any derivation of the Imen'kovo from the Sântana de Mureş-Chernyakhov culture, since the origins of the former predate the Hunnic invasion, which, according to Sedov, has triggered the eastward migration of the Sântana de Mureş-Chernyakhov people to the Samara Bend. That the Imen'kovo culture in that region of the Middle Volga was the result of a migration is therefore not a conclusion drawn from the archaeological evidence, but an idea based on the assumption that only migration can explain cultural changes. Recent studies, without rejecting the possibility of short-distance population movements, suggest however that the Imen'kovo culture is the result not of migration from western Ukraine, but of cultural mestizaje, for it appears to be a combination of elements that appear in other cultures of the Kama and Volga region..$^{35}$ Nor can a case be made for the lands

32 Bogachev, "Problemy etnokul'turnogo vzaimodeistviia", pp. 108-110.

33 Matveeva, "O proiskhozhdenii". See also Matveeva, "K voprosu o proiskhozhdenii pogrebenii s trupopolozheniiami”; Matveeva, Srednee Povolzh'e, pp. 65-74.

34 Sedov, Slaviane, p. 315. Fodor, "K voprosu ob etnicheskoi prinadlezhnosti", p. 106 has rightly noted that the idea has first been put forward by Aleksandr Smirnov (Smirnov, "Nekotorye spornye voprosy").

35 Viazov/Stashenkov, "Kul'turno-khronologicheskie gruppy", p. 49. Although Viazov, "O proiskhozhdenii pakhotnykh orudii” still derives Imen'kovo plowshares from Sântana de Mureş-Chernyakhov prototypes, Viazov, "O proiskhozhdenii toporov" argues that axes found on Imen'kovo sites derive from prototypes in the Kama region. To be sure, Leonid Viazov does not draw any conclusions about migration from his studies of tools and weapons, respectively. 
in the Samara Bend region being emptied in the mid-7th century, because of the migration of the Imen'kovo people to the Middle Dnieper. Recent excavations on sites located at the foot of the Zhiguli Mountains (e.g., Osh-Pando-Ner') have produced materials dated to the first half of the 8th century representing a mixture of cultural traditions, one of which is clearly Imen'kovo. In the words of a Russian archaeologist commenting on those finds, "this is not migration, but acculturation". ${ }^{36}$

Elsewhere, the fundamental assumption is that a migration must have taken place, if settlements and cemeteries appear suddenly in a region that has previously been sparsely populated. For example, a vacuum of population is postulated in order to explain the migration that led to the rise of the $5^{\text {th- }}$ to early 7 th-century archaeological group known as Elbląg in the Lower Vistula region of northern Poland. During the 5 th century, the Wielbark population is believed to have moved to the south. In the early 6 th century the lands that had thus been vacated were occupied by immigrants from the Sambian Peninsula (Samland) and Natangia, in what is now the Kaliningrad oblast' of Russia. This wave of Baltic-speaking newcomers supposedly moved along the Vistula Lagoon and populated its entire southern shore, from the Pasłęka all the way to the Lower Vistula. ${ }^{37}$ Where no assumptions can be made about a vacuum of population, migration is identified archaeologically through the sudden appearance in a given region of dress accessories without any local traditions or parallels. For example, only a few types of Viking-age female dress accessories found in Finland and the Baltic countries are known that have parallels in Scandinavia, and they usually appear singly and in graves which are in all other respects typically local. By contrast, in northwestern Russia, practically all types of Scandinavian female dress accessories are represented, and they appear in typically Scandinavian combinations in the graves, which also conform in other respects (e.g., burial rite) in a remarkable way to the Scandinavian culture. While artifacts of Scandinavian origin related to religion or magic, such as Thor's hammer rings, are practically absent from Finland and the Baltic countries, they are numerous in Russia. This polarized distribution of artifacts has therefore been interpreted as evidence of a large immigration of whole families from Scandinavia to Russia. The migration must have been sufficiently

$36 \quad$ Rastoropov, "Voprosy etnokul'turnoi istorii", pp. 46-47.

37 Okulicz, "Osadnictwo ziem pruskich", pp. 32 and 31 pl. III; Nowakowski, "Zmierzch dawnych czasów", p. 278. By contrast, the neighboring Olsztyn group in Mazuria (northeastern Poland) is believed to be the result of a late 5 th- or early 6th-century "return migration" from the region of the Middle Danube (Nowakowski, "Die Olsztyn-Gruppe", pp. 175 and $177 ; 176$ fig. 5). 
strong for those distinctive features to be preserved over a couple of generations. ${ }^{38}$

Although mentioned in written sources, the migrations of the Sermesianoi and the Adrianopolitans mentioned above have no archaeological correlates. The same is true for the migration of the Croats. In his De administrando imperio, Emperor Constantine VII Porphyrogenitus (913-959) had the Croats arriving to Dalmatia "to claim the protection of the emperor of the Romans Heraclius" ${ }^{39}$ Where did they come from? "The Croats who now live in the region of Dalmatia are descended from the unbaptized Croats, also called 'white', who live beyond Turkey [Hungary] and next to Francia". ${ }^{40}$ According to Emperor Constantine, the migrants came to Dalmatia under the leadership of five brothers (Kloukas, Lobelos, Kosentzis, Mouchlo, and Chrobatos) and two sisters (Touga and Bouga) and conquered the land from the Avars. Generations of historians have taken the story at face value, and many archaeologists are still looking for evidence to confirm it. ${ }^{41}$ Recently, however, it has been noted that Emperor Constantine's account is an adaptation of a story found in Herodotus (IV 33.3): "the Croatian migration did not take place, but... Constantine Porphyrogenitus created it relying on the literary models traditionally applied to described the Landnahme of Scythian Barbarians".42 Moreover, there is no archaeological evidence of a new population arriving in Dalmatia in the early 7 th century. On the contrary, the region seems to have experienced a dramatic

38 Jansson, "Warfare, trade or colonization?", pp. 26-27. For iron torcs with Thor's hammers in Eastern Europe, see Novikova, "Iron neck-rings". Such rings have also been found in Poland, especially in Pomerania, see Gardeła, Scandinavian Amulets and "Amulety skandynawskie". In Pomerania, the sudden change of burial rites from cremation to inhumation is attributed to a Scandinavian immigration (Sikora, "Akulturacja, wymuszona chrystianizacja czy migracja?").

39 Constantine Porphyrogenitus, De administrando imperio 31, ed. Moravcsik/Jenkins, pp. 146 and 147. The Croats settled down in Dalmatia "by mandate of Heraclius" (ibid., pp. 148 and 149).

40 Constantine Porphyrogentius, De administrando imperio 31, ed. Moravcsik/ Jenkins, pp. 146 and 147. See also, ibid., 30, pp. 142 and 143: "But the Croats at that time were dwelling beyond Bavaria, where the Belocroats are now".

41 See Hauptmann, "Dolazak Hrvata"; Antoljak, "Hrvati u Karantaniji"; and Kardaras, "The settlement of the Croats and the Serbs". For a good historiographic survey, see Dzino, Becoming Slav, Becoming Croat, pp. 99-117. According to Jarak, "Zapažanja o grobljima", since no drastic changes in earring typology took place in Croatia between the 8th and the gth centuries, one has to admit that the Croats came to Dalmatia in the 7 th century, as indicated in the De administrando imperio.

42 Borri, "White Croatia", p. 231. For Emperor Constantine's political motivations of making Emperor Heraclius invite the Croats to Dalmatia, see Dzino, "Pričam ti priču", pp. 159-160. 
population decline during the first half of the 7 th century, with only coastal towns surviving. The earliest burial assemblages that have been attributed to the Croats cannot be dated before the year $700 .{ }^{43}$

A somewhat different situation concerns the migration of the Pechenegs. Their movement across the Eurasian steppe is believed to have been triggered by the rising power of the Qarluqs and the attacks of the Oghuz. The Pechenegs then crossed the Volga and the Don, and invaded the lands north of the Black Sea inhabited by the Magyars. ${ }^{44}$ The archaeological correlates of that migration reconstructed by historians on the basis of a mixture of historical and linguistic arguments are hard to find, for none of the so-called nomadic graves in the steppe lands can be securely attributed to the Pechenegs alone. There is incontrovertible evidence of their migration across the Danube into the Balkan provinces of the Byzantine Empire. In 1046, a Pecheneg chieftain named Kegen fled from a rival together 20,00o fellow tribesmen across the Danube and took shelter on a "little island in the river", not far from Dristra (nowadays, Silistra, in northern Bulgaria). The Pechenegs received "three of the fortresses standing on the banks of the Danube and many hectares", and Kegen was "inscribed among the friends and allies of the Romans". ${ }^{45}$ Kegen converted to Christianity, and was then given the supreme command of the troops from Paristrion, Thrace, and Bulgaria. That this is no literary construction is clearly demonstrated by his seal found in Silistra, the inscription of which reads "Lord, have mercy upon the magistros John Kegen, the archon of Patzinakia". ${ }^{4}$

Despite clear evidence from the written sources, the archaeological correlates of the Pecheneg migration to the Balkans are elusive. Archaeologists have linked the destruction of settlements in the northern Balkans to the Pechenegs raids, but the evidence of a Pecheneg settlement is circumstantial. Various categories of artifacts have been attributed to them, from clay kettles and handmade pottery to leaf-shaped pendants with open-work ornament, horsemanshaped amulets, jingle bells, appliques and bridle mounts, arrowheads, and

43 For the archaeology of the late 6th and early 7 th century in the territory of present-day Croatia and Slovenia, see Curta, "The early Slavs in the northern and eastern Adriatic region", pp. 321-322; Dzino, Becoming Slav, Becoming Croat, pp. 121-128.

44 Zimonyi, "A besenyők nyugatra". In a belated reply to László Vajda, Fodor, "Ecology and migrations", p. 80 regards the Pecheneg migration across the Volga, the Don, and the Dnieper rivers as the best example of a "chain migration".

45 Skylitzes, Synopsis, ed. Thurn, p. 456, transl. Wortley, p. 428. For this episode see Curta, "The image and archaeology", pp. 153-154.

46 Iordanov, "Sceau d'archonte" and "Pechati". For Kegen's title of magister, see Dudek, "Pieczęć magistra Jana Kegena". For Patzinakia as the region of the theme of Paradounavon in what is now northeastern Bulgaria, see Madgearu, "The periphery", p. 51. 
stirrups. However, no warrior graves have so far been found, despite the overwhelming evidence in the sources of devastation and plundering done by groups of armed men. Moreover, the ethnic identification of clay kettles and leaf-shaped pendants as Pechenegs is highly problematic. ${ }^{47}$ While the archaeological visibility of the Pechenegs in the lands north of the Danube is associated with burials in prehistoric mounds, there are no 11th-century graves in burial mounds in Bulgaria. Burials with the skull and legs of a horse deposited next to the human skeleton, which many regard as typical for the steppe nomads, are also very rare. ${ }^{48}$ The detailed examination of the cemetery excavated in Odărci-the largest ntth-century cemetery in northern Bulgaria-shows no traditions common to the community burying their dead there and to those in the lands north of the Black Sea and the Lower Danube. ${ }^{49} \mathrm{~A}$ general tendency towards the adoption of the Christian burial, including coffin-like structures associated with stone-lined graves as well as burial in and around cemetery chapels, seem to have been associated with the reinterpretation of a number of traits that are not prominent in the archaeological record of the East European steppe lands - trepanation, charcoal in the grave pit, and bridle mounts recycled as dress accessories. The absence from the region of any signs of military posturing so typical for burial in prehistoric barrows north of the river Danube is simply the other side of the same coin. There is, in other words, no direct archaeological correlate of the migration of the Pechenegs. Elements of the archaeological evidence from large cemeteries, such as Odărci (the chronology of which coincides in time with the events known from written sources), which could be regarded as reflections of the traditions of the steppe, "may well have been 'quotes' designed to give a 'Pecheneg look' to a regional identity at a time of considerable political and social turmoil" and in an area in which the Pechenegs of Paristrion were a leading political group. ${ }^{50}$

In three cases concerning migrations into the Carpathian Basin, the archaeological evidence backs the conclusions drawn from the written sources. Emperor Constantine viI Porphyrogenitus knew that the Magyars (whom he called "Turks") "had of old their dwelling next to Khazaria, in the place called Lebedia". Defeated by the Pechenegs, the Magyars "split into two parts. One part went eastwards and settled in the region of Persia, and they to this day are

47 Curta, "The image and archaeology", pp. 159-162 and 168-170; Fiedler, "Zur Suche", pp. 271-279.

48 For an isolated burial with the head and legs of a horse deposited on the left side of a human skeleton, which was recently found in Plovdiv and attributed to the Pechenegs, see Ivanov, "Novi danni", pp. 406 and 405 fig. 6.

49 Curta, "The image and archaeology", pp. 170-178.

5o Curta, "The image and archaeology", p. 181. 
called by the ancient denomination of the Turks 'Sabartoi asphaloi'; but the other part ... settled in the western region, in places called Atelkouzou, in which places the nation of the Pechenegs now lives".51 The Pechenegs had in fact expelled the Magyars from their abodes, and the latter "came and settled in the land which they now dwell in", i.e., Hungary. ${ }^{52}$ The account of the continuous migration of the Magyars from east to west, modeled after that of the Chosen People, has been traditionally taken at face value by many historians, and only recently, some commentators of Emperor Constantine's work have pointed out the obviously literary construction of that account. ${ }^{53}$ In many respects, therefore, the problem of the Magyar migration as depicted in the written sources is not different from that of the Croat migration. However, Hungarian archaeologists have been able to isolate a number of artifacts clearly associated with the first generation of Magyars in the Carpathian Basin, primarily based on analogies with finds in Eastern Europe. For example, the belt set from Karancslapujtő has analogies on sites in Mordvinia (the present-day Mordovian Republic), while the horse gear in the female burial in Szakony has parallels in Belymer, Tankeevka and Borshevo-all sites in the Middle Volga region. ${ }^{54}$ Most analogies point to sites associated with the late 8th- to mid-gthcentury Karaiakupovo culture: burial construction, orientation and position of the body inside the burial pit, burial goods associated with male and female

$5^{1}$ Constantine Porphyrogentius, De administrando imperio 38, ed. Moravcsik/Jenkins, pp. 170-173. Most historians have traditionally taken the story about the Sabartoi asphaloi at face value, e.g., Ducellier, "Les sources byzantines", p. 53. For recent doubts, see Bata, "The Turks" and Bubenok, "Savarty-asfaly".

52 Constantine Porphyrogenitus, De administrando imperio 39, ed. Moravcsik/Jenkins, pp. 176-177. Emperor Constantine mentions Trajan's bridge over the Danube (now at Drobeta-Turnu Severin, in southwestern Romania), Belgrade, Sirmium (Sremska Mitrovica, in northern Serbia), and "great Moravia" in relation to the lands in which the Magyars have settled.

53 For the continuous migration of the Magyars, see Barna, "A magyarok útjáról"; Fodor, In Search of a New Homeland; Váczy, "The Byzantine emperor"; Róna-Tas, "The migration of the Hungarians", pp. 246-248; Tóth, Levediától a Kárpát-medencéig; Múcska, "Migracja i etnogeneza". For the historioghraphy of the Magyar ethnogenesis and migration, see Ovchinnikova/Gyóni, Protovengry. For cracks in the traditional interpretation of Emperor Constantine's account, see Szabados, “A legyőzött magyarok ming hódítók?” Archaeologists have also clung onto the "serial migration model" created on the basis of De administrando imperio, with different archaeological cultures corresponding to various stages of the migration, and each one of those stages being responsible for some key change in the Magyar culture and language. See the critical remarks of Sindbæk, "A Magyar occurrence", p. 153 .

54 Mesterházy, "Die Landnahme der Ungarn”, pp. 28-31. Contra: Vavruš, "Prvá mad'arská generácia", p. 186. For the finds from Karancslapujtő and Szakony, see Dienes, Die Ungarn, fig. 16 and "A karancslapujtő honfoglalás kori őv". 
graves (especially mortuary masks), the deposition of horse remains (skull and limbs). ${ }^{55}$ In other words, the archaeological evidence points to the appearance in the 1oth century of a new, coherent culture in the Carpathian Basin, which is different from those of the previous period. This culture has been described as "a wide, homogeneous unit, with contacts reaching to the steppe lands in Eastern Europe and beyond", even though some of its features seem to have developed locally. The beginnings of the new culture coincide in time with the immigration of the Magyars known from the written sources. ${ }^{56}$

Three centuries earlier, a similarly new and coherent culture has made its appearance in the Carpathian Basin. New burial customs and artifact types, for which there is no analogy in the whole of Europe, have been associated with the immigration of the Avars, as reconstructed based on the information in Paul the Deacon's History of the Lombards that was written more than 150 years after the events. ${ }^{57}$ István Bóna believed that the only analogies for pits with cremated remains of horse gear (including stirrups) and, occasionally, weapons (lance heads) were in Central Asia, while Sassanian influences were reflected in such categories of artifacts as weapons, dress accessories, as well as gold- or silverware. ${ }^{58}$ "Nomadic" belt sets, swords with long blades, bow reinforcement plates, remains of quivers, and many other artifacts were equally regarded as new for the picture of European archaeology. However, only rarely can contemporary parallels for the earliest artifact-categories associated with the earliest Avars be found outside the Carpathian Basin. ${ }^{59}$ Apple-shaped, cast stirrups with elongated suspension loops and flat treat slightly bent inwards are typical for the earliest assemblages associated with the Avar immigration, and are the earliest European stirrups known so far. However, there are no parallels for those artifacts on any site in Eurasia that may be dated prior to the migration of the Avars. ${ }^{60}$ Nonetheless, the population that buried its dead in

Gołębiowska-Tobiasz, "The Hungarians", pp. 41-42.

56 Langó, "Archaeological research", p. 181.

57 Paul the Deacon, History of the Lombards I 27 and II 7, ed. Waitz, pp. 80 and 89. Despite efforts to reassess the History of the Lombards as a literary work, Paul the Deacon's account of the Avar migration has been remarkably resistant to historical criticism, particularly the idea that the Lombards bestowed their "own abode, that is, Pannonia" upon the Avars. Pohl, Die Awaren, pp. 50-51 takes the account at face value, even though he recognizes "legendary" elements in the story of how Cunimund, the king of the Gepids, was defeated and killed in war with the Lombards and their Avar allies.

58 Bóna, "Die Geschichte der Awaren", pp. 443-444.

59 Bálint, Die Archäologie der Steppe, p. 149; Bálint, "Probleme”, p. 214. Attempts to identify Central Asian Avars by means of physical anthropology bore no fruits (Tóth, "Északdunántul avarkori népességének").

6o La Salvia, "La diffusione della staffa"; Curta, "The earliest Avar-age stirrups". 
cemeteries located to the east from the Middle Tisza river migrated there from the steppe lands in southern Ukraine, as indicated by the typical graves with tunnel-shaped shafts that have no parallels in the Carpathian Basin. ${ }^{61}$ Two of the men buried in the $7_{\text {th }}$ century in the Komárom-Shipyard cemetery (Slovakia) were accompanied in death by spears, the shafts of which were made of black mulberry, a species of tree that did not exist in the Carpathian Basin during the early Middle Ages, but was widely spread in Central and Eastern Asia. ${ }^{62}$ During the 6th century, the area between the Danube and the Tisza in what is today Hungary, was only sparsely inhabited, and may well have played the role of a "no man's land" between the Lombard and Gepid territories. It is only after ca. 600 that this area was densely inhabited, as indicated by a number of new cemeteries that came into being along the Tisza and north of present-day Kecskemét. ${ }^{63}$ There can therefore be no doubts about the migration of the Avars into the Carpathian Basin, even though it was probably not a single event and did not involve only one group of population, or even a cohesive ethnic group. ${ }^{64}$

Paul the Deacon, the only author directly referring to the migration of the Avars into the Carpathian Basin, did so in the context of his account of the migration of the Lombards from that region, across the Alps, to Italy. ${ }^{65}$ Many scholars still regard the movement of the Lombard to Italy as "spectacular", a "migration avalanche". Unlike other migrations, that of the Lombards is treated as a "total migration", in that it was not just a group, but also the entire population that moved out from the Carpathian Basin into the Italian

$61 \quad$ Lőrinczy, "Kelet-európai steppe népesség”; Türk, "O novykh rezul'tatakh". For a slightly different argument, see Gulyás, "Újabb adatok". For an anthropological study of the immigrants, see Fóthi/Lőrinczy/Marcsik, “Arkheologicheskie i antropologicheskie sviazi”.

62 Trugly, “Komárom-Hajógyár”, p. 209.

63 Balogh, "A Duna-Tisza köze", pp. 59-64. For an "explosion" of sites in the whole Carpathian Basin shortly after the year 6oo, see also Szenpéteri, "Was die Verbreitungskarten erzählen...", pp. 334 with fig. 7.1.

64 A fierce debate surrounds István Bóna's idea that the change in archaeological culture, which he dated ca. 675 , was to be explained in terms of another migration of Turkic elements from the steppe lands in Central and Inner Asia (Bóna, "Die Geschichte der Awaren", pp. 455-456). This idea was embraced by others who pointed to new cemeteries being opened at different locations during the last quarter of the $7_{\text {th }}$ century (Tomka, "Die Frage"). For a thorough critique of Bóna's theory, see Bálint, "Der Beginn der Mittelawarenzeit". The debate has been fueled by nationalist concerns deriving from Gyula László's idea that the new immigrants were speakers of a Ugric language, which made the Hungarians native to the Carpathian Basin about two centuries before the Magyar migration to that area. See László, “A kettős honfoglalásrol”; Kristó, "Nyelv és etnikum”; Madaras, "Az Alföldi avarság”; Magyar, "A honfoglalás (kettős honfoglalás) legújabb”; Olajos, "De la théorie"; Fodor, "A 'kettős honfoglalás".

65 Paul the Deacon, History of the Lombards II 8, ed. Waitz, p. 90. 
Peninsula. ${ }^{66}$ While the mass character of the Lombard migration to Italy has been recently questioned, no one seems to doubt it. A strategy for acquiring a better social position, the migration of the Lombards from the lands now in southern Hungary has been associated with grave robbing, itself a phenomenon interpreted as a sign of abandonment of the old settlements. ${ }^{67}$ Historians have also not questioned the movement of the Lombards from the lands to the north into those to the south of the river Danube. Although none of the phases (and corresponding stops) of that migration, as related in the Origo gentis Langobardorum, is confirmed by any other sources, that version of the Lombard migration is taken for granted. ${ }^{68}$ Jaroslav Tejral has long insisted upon the distinction between various cultural horizons in the archaeology of the 4th to 6th centuries in the Czech lands and Moravia; the last horizon represents the arrival of a new group of people from the lands along the Elbe river-the Lombards of the Origo gentis. ${ }^{69}$ The results of the isotope analysis of tooth enamel from skeletal materials from two 6th-century cemeteries in Moravia (Lužice and Holubice) seem to confirm the idea of a migration taking place shortly before the year $500 .{ }^{70}$ The migration of the Lombards to the lands south of the river Danube now within Hungary has also received much attention from archaeologists. The first phase (ca. 510 to ca. 535) is believed to be associated with relatively small cemeteries (80-9o graves) in use for a couple of generations. Such cemeteries were not fundamentally different from much larger ones of the previous, pre-Pannonian phase in Austria or Moravia. However, graves of males in such cemeteries have produced a greater quantity and variety of weapons. During the second phase (535-550), new cemeteries appear in southern Pannonia, that were considerably smaller (40-50 graves), because they were in use only for a very short period of time. Those cemeteries typically include "archaic" material of Moravian provenance, such as handmade pottery of the Elbe type, often associated with urn cremations. The last phase (550-568) is supposedly identifiable by means of comparison with the earliest finds in Italy. ${ }^{71}$ The existence of short-distance movements of population

66 Borgolte, "Eine langobardische 'Wanderlawine', pp. 293-295, blames Walter Pohl for the propagation of such myths.

67 Barbiera, Changing Lands, p. 146. See Freeden, "Wer stört Gräber?".

68 Origo gentis Langobardorum, ed. Waitz, pp. 1-6. For the traditional interpretation of the migration of the Lombards to Pannonia, see Borovszky, "A langobardok vándorlása"; Jarnut, Geschichte, p. 19; Bystrický, St'ahovanie národov, pp. 81-105. For a critique of that approach, see Pohl, "Migration und Ethnogenese", p. 1.

69 Tejral, "Zur Unterscheidung”.

70 Tejral, "K současnému stavu", p. 59.

71 Vida, "Aufgaben und Perspektiven”, p. 346; Keresztes, “Fegyveres langobardok”, p. 481. See also Vida, "La ricerca". The distinction between the three phases of the Lombard migration 
across Transdanubia (the lands to the south and west of the river Danube, now in Hungary and Austria) during the 6th century is also confirmed by the results of the stable isotope analysis of tooth enamel from the skeletal material of the newly excavated cemetery in Szólád, which came into existence during the second phase of the Lombard migration. Two thirds of those buried in that cemetery were not of local origin. Children have been buried in that cemetery, who had been born elsewhere, most likely in northern Transdanubia, during the first third of the 6th century. There were also local children, but not adults, in the Szólád cemetery. This seems to point to a relatively short period during which the cemetery was in use, perhaps no more than a generation. ${ }^{72}$ The underlying assumption is, of course, that those abandoning the cemetery in Szólád moved to Italy.

Without skeletal material from large cemeteries and no written sources to describe the migration of the Slavs in explicit terms, archaeologists and historians alike have embraced an outdated model ultimately inspired by research in linguistics. Many of them still stubbornly stick to that, even though the evidence accumulated over the last few decades clearly points to a completely different interpretation. ${ }^{73}$ To be sure there is only one medieval author that specifically mentioned Slavs ("who are also called Avars") moving from their lands "on the far side of the river Danube" to the Balkans and establishing themselves in Salona (near present-day Split, in Croatia). Moreover, that late source is, again, Emperor Constantine viI Porphyrogenitus. His story looks more like an attempt to explain the particular situation of Salona and of the former province of Dalmatia. ${ }^{74}$ At any rate, there is no indication of a Slavic migration from the lands north of the Danube into Dalmatia either before or during the reign of Emperor Heraclius, whose name is associated to the "story of the province of Dalmatia". ${ }^{75}$ No 6th-century author mentions the migration of the Slavs to the Danube, or their movement across that river in order to set-

into the lands south of the river Danube goes back to István Bóna (Vida, "Die Langobarden", pp. $75^{-76) \text {. }}$

72 Peters et al. “Schmelztiegel Balaton?", p. 354. For Szólád, see Freeden/Vida, “Ausgrabung”.

73 Biermann, "Kommentar", pp. 339-340 and 344 even compares the Slavs with the Bantu, both with migrations identified linguistically. For a mise-au-point, see Curta, "The early Slavs in Bohemia", pp. 728-729 and 736-737.

74 Constantine Porphyrogenitus, De administrando imperio 29, ed. Moravcsik/Jenkins, pp. 122-125. In the following Chapter (30), those putting to the sword the city of Salona and making themselves masters of "all the country of Dalmatia" are Avars, not Slavs (ibid., pp. 142-143). For the sources and interpretation of the story, see Dzino, Becoming Slav, Becoming Croat, pp. 111-112.

75 Constantine Porphyrogenitus, De administrando imperio 29, ed. Moravcsik/Jenkins, pp. 124-125; Žiković, De conversione, pp. 103, 106, and 109; Curta, "The early Slavs in the 
tle permanently in the Balkan provinces of the early Byzantine Empire, or anywhere else in Europe.$^{76}$ Attempts to delineate a migration of the Slavs based on place names currently in use in East Central and Eastern Europe have produced dubious results. ${ }^{77}$

Archaeologists have turned to pottery as an indicator of both Slavic ethnicity and migration. The handmade pottery of the so-called Prague type has become the hallmark of the culture believed to be the contrast agent allowing the archaeological visibility of the Slavic population movements. Since the Slavs are "represented" by the Prague culture, the study of the migration of the Slavs was the study of how that culture expanded across large parts of eastern and southeastern Europe between the 6th and the 8 th centuries. ${ }^{78}$ Various phases of the migration are thus based on the presence of the earliest phases of the Prague-type pottery in particular territories. ${ }^{79}$ There are serious problems with such an interpretation of the archaeological evidence. First, to this day, the handmade pottery of Prague type lacks a clear definition and typology. It is not even clear whether such a type truly existed. Nor is it known where and when it may have originated and how it may have spread over a vast area, from the

northern and eastern Adriatic region", p. 322. For a more traditional take on those issues, see the contribution of Koder in the present volume.

76 For a contrary, but utterly wrong opinion, see Fusek, "Drevnee slavianskoe naselenie", p. 153 .

77 Udolph, “Die Landnahme der Ostslaven”, pp. 334 map 1, and 335 map 2. Place names have also been used, with similarly dubious results, to claim a movement of the Slavs in the contrary direction, from the Danube to the lands in East Central and Eastern Europe (Kunstmann, "Wie die Slovenen an den Ilmensee kamen" and "Waren die ersten Přemysliden Balkanslaven?", p. 42). Responsible for this migration from south to north are supposedly the Avars or the Bulgars. The idea of a Slavic migration from south to north enjoys increasing popularity among Russian and Ukrainian archaeologists (Prykhodniuk, "Osnovni pidsumky", pp. 18-19; Kuz'min, “O vremeni”; Kazanski, "Les Slaves", pp. 27-30; Sedov, "O rasselenii dunaiskikh slavian" and "Migraciia dunaiskikh slavian"; Shcheglova, "Volny rasprostraneniia veshchei”, pp. 6o-61; Iushkova, "North-western Russia", p. 149). For the historiography of the problem, see Koneckii, "Slavianskaia kolonizaciia".

78 Machinskii, "Migraciia slavian”, pp. 31-37; Měřínský, České země, pp. 46 and 57-59; Biermann, "Kommentar", p. 399. For the migration of the Slavs as a migration of multiple archaeological cultures, see Pleterski, Etnogeneza Slovanov, p. 34 fig. 7. Kobyliński, "The Slavs", p. 531 believes that sunken-floored buildings are a better contrast agent for tracing the migration of the Slavs; Sedov, "Venedy-slaviane" prefers the so-called "Slavic" bow fibulae.

79 Gavritukhin, "Nachalo", pp. 73-74 and 78-82. The idea of tracking the migration of the Slavs by means of a study of the chronology of cultural changes over a vast area and a longer period of time has been first put forward by Godłowski, "Die Frage" (reprinted in Godłowski, Frühe Slawen, pp. 85-122). 
Pripet marshes to Bohemia and Greece. ${ }^{80}$ Second, there is still no firm chronology of the ceramic assemblages attributed to the Prague culture. For example, it is believed that the Slavs reached eastern Mecklenburg in the late $5^{\text {th }}$ or early 6 th century, at the same time as they entered Silesia, eastern Brandenburg, and the northeastern part of the Carpathian Basin. They were in Moldavia during the first half of the 6th century, and their expansion into the Balkans started after the middle of that century. Soon after that, they also reached Bohemia. ${ }^{81}$

However, German archaeologists believe that the bearers of the Prague culture who reached northern Germany came from Bohemia and Moravia, which means that their immigration could not have taken place before the middle of the 6 th century. As a matter of fact, no archaeological assemblage attributed to the Slavs either in northern Germany or in northern Poland may be dated earlier than ca. $700 .{ }^{82}$ Conversely, the archaeological assemblages attributed to the Slavs (Sclavenes) in southern and eastern Romania are earlier than any in central Ukraine, the Middle Dnieper region, or any other part of Eastern Europe. ${ }^{83}$ While it is true that during the second half of the 6th and the first half of the 7 th century, the number of settlements increased considerably in eastern Romania, in contrast to the situation of the previous two centuries, the increase is not necessarily the result of migration. It may instead reflect the itinerary agriculture and the pastoralist activities of the local population. ${ }^{84}$ There are to date no indications of an expansion of the Prague culture into the Balkans before 600 and very few indications after that of any archaeological evidence that could be attributed to the Slavs. ${ }^{85}$ Meanwhile, none of the archaeological assemblages associated with the so-called Prague culture in Bohemia and Moravia may be dated before $600 .{ }^{86}$

8o Curta, "The Prague type" (reprinted in Curta, Text, Context, pp. 87-130). The notion of a "Prague type" of pottery was first introduced by Borkovský, Staroslovanská keramika, but various attempts at formal description and analysis have so far failed to isolate the Prague type.

$81 \quad$ Gavritukhin, "Nachalo", p. 84.

82 Brather, Archäologie, p. 59; Dulinicz, "Najstarsza faza" and Frühe Slawen, pp. 275-287. According to Brather, "Einwanderergruppe oder Regionalentwicklung?", p. 343, the migration of the Slavs into northern Poland and Germany is archaeologically invisible.

83 Curta, Making of the Slavs, pp. 335-338.

84 Teodor, "Evoluţia demografică", p. 275 (compared to the number of settlements dated between the $5^{\text {th }}$ and the 6 th century, the number of those dated between ca. $55^{\circ}$ and ca. $65^{\circ}$ rose by 55 to 60 percent). The link between itinerary agriculture and the appearance of new settlements is best illustrated by the excavations in Dulceanca (southern Romania), for which see Curta, Making of the Slavs, pp. 276 and 308.

85 Curta, "The beginning of the Middle Ages", pp. 196-197.

86 Curta, "Utváření Slovanů", pp. 681-682. Most radiocarbon dates now available for sites in Bohemia and Moravia are late, despite occasional claims to the contrary (Profantová/ 
One of the most egregious problems with the current model of the Slavic migration is that it is not at all clear where it started. There is in fact no agreement as to the exact location of the primitive homeland of the Slavs, if there ever was one. The idea of tracing the origin of the Slavs to the Zarubyntsi culture dated between the 3rd century B.C. and the first century A.D. is that a gap of about 200 years separates it from the Kiev culture (dated between the 3 rd and the 4 th century A.D.), which is also attributed to the Slavs. ${ }^{87}$ Furthermore, another century separates the Kiev culture from the earliest assemblages attributed to the Prague culture. It remains unclear where did the (prehistoric) Slavs go after the first century, and whence they could return, two centuries later, to the same region from which their ancestors had left. The obvious cultural discontinuity in the region of the presumed homeland raises serious doubts about any attempts to write the history of the Slavic migration on such a basis. There is simply no evidence of the material remains of the Zarubyntsi, Kiev, or even Prague culture in the southern and southwestern direction of the presumed migration of the Slavs towards the Danube frontier of the Roman Empire.

Moreover, there is no agreement regarding the possible reasons for which the presumed migration happened in the first place. While Peter Heather made the Slavs fill the "power vacuum created by Przeworsk culture collapse" in the late $5^{\text {th }}$ or early 6th century, the Russian archaeologist Valentin Sedov treated the Slavs as bearers of the Przeworsk culture, and wrote of their $5^{\text {th- }}$ century migration to the north and to the northeast, as far as the lakes Ilmen and Peipus. ${ }^{88}$ Why did the Slavs move out of their primitive homeland? Some authors blame the combined effects of the Hunnic invasion and climate change, with temperatures much lower than in the previous 2,00o years, which

Bureš, "Bedeutende frühe slawische Siedlungen", p. 191; Profantová, "Slaviane”, pp. 100 and 102). When multiple radiocarbon dates contradict her theory of an early Slavic culture in Bohemia, Nad'a Profantová finds excuses: "The migration hypothesis cannot be tested with the help of the natural sciences" (Profantová, "Cultural discontinuity", p. 260).

87 Furas'ev, "Fenomen"; Pleterski, "Etnogeneza Slavena”, pp. 15 fig. 3; 20. For a rebuttal, see Curta, "Four questions", pp. 290-293.

88 Sedov, "Nachalo" and "Sever Vostochno-Evropeiskoi ravniny", pp. 17-18. The Slavs presumably looked for good lands for agriculture, and Minasian, "Problema slavianskogo zaseleniia" has even defined a set of agricultural implements as typical for the Slavic agriculture of the 6th century. The appearance of that set in any given region was then treated as evidence of a Slavic migration. For critical remarks about those theories, see Tvauri, "Migrants or natives?" pp. 26-27. Others believe that a Slavic presence in the Novgorod lands cannot be dated before the mid-gth century (Kuz'min/Mikhailova, "Novye materialy", pp. 143 and 146). 
made living conditions in the forest zone of Eastern Europe particularly bad. ${ }^{89}$ The out-migration was the result of an ecological crisis, the main reasons for which were podsolization (caused by slash-and-burn form of agriculture) and epizootics (itself caused by the depletion of soils of basic metals, especially cobalt)..$^{90}$ To others, no assumption of demographic pressure, external forces, or ecological catastrophe is needed to explain the southward migration of the Slavs. Instead, a "simple under-pressure mechanism" must be favored: the Slavs were attracted to the Balkans because that region had been depleted by Justinian's plague. In fact, the migration was supported by the Empire, which exploited the Slavs as easily accessible work force that the imperial government needed after the demographic collapse of the Balkans. ${ }^{91}$ Still others think that the Slavic migration was "a response to inequalities of wealth and development and, in that respect, is very similar to modern migrations". The Slavs were simply poor, and migration became "a well-entrenched strategy among many Slavic populations", which kept on moving. For the Slavs, migration was a means of carrying on traditional lifestyles, "including a very small scale of social organization". Their extended familial settlements spread across Central Europe simply because of population growth. "They may have lacked circuses, togas, Latin poetry, and central heating, but the Slavs were as successful in imposing a new social order across central and Eastern Europe as the Romans had been to the west and south". ${ }^{2}$

Even with such elucubrations, the lack of archaeological evidence to support them makes it increasingly difficult to maintain the idea of the Slavs as a population expanding physically and rapidly over large areas of Eastern and East Central Europe, colonizing "vacant" places, and carrying their culture with them. ${ }^{93}$ Migrationism in this particular case is associated with a stubborn refusal to abandon a model of historical development fashioned by linguists primarily on the basis of the family tree of languages, which located the Slavic homeland in the epicenter of the modern distribution of Slavic languages. New

$89 \quad$ Sedov, "Proiskhozhdenie slavian", pp. 57-58, and "Osnovnye voprosy", p. 435. The warming of the climate supposedly triggers migration as well (Oleinikov, "Kul'tura dlinnykh kurganov", p. 173). Shevchenko, "Ekologicheskii krizis" and $v$ zone slavianskogo etnogeneza, pp. 139-142, 143, 149-151, and 199: the "cobalt deficiency" led to an ecological catastrophe, which led to migration.

91 Sołtysiak, "The plague endemic", p. 361.

92 Heather, Empires and Barbarians, pp. 446-447. The Slavs from "Dulcinea" (probably a corrupted form of Dulceanca, the name of an archaeological site in southern Romania) migrated into the Roman Empire. In Heather's Don Quixotesque version of early Slavic history, social change starts in El Toboso.

Urbańczyk, "Foreign leaders", p. 263. 
approaches to the spread of (Common) Slavic inspired by sociolinguistics had absolutely no impact on the archaeological and historical research on the early Slavs. ${ }^{94}$ Equally neglected by both archaeologists and historians remains the idea that instead of migration of Slavs, one should speak of the "expansion of Slavicism, as the expansion of a cultural model", which was adopted by the inhabitants of various parts of Eastern Europe together with the Slavic language and associated patterns of material culture. ${ }^{95}$

Several conclusions may be drawn from this survey of the current state of research on migrations in early medieval Eastern Europe. First, migration is still conceptualized as "invasion" or a "large-scale population movement". There is yet no sign of the theoretical impact of the recent resurgence of scholarly interest in migration, which has been inspired by concerns with connectivity, colonial studies, postcolonial perspectives, and entangled situations. ${ }^{96}$ Nor is there any concern with migration as a "multi-layered process". Equally absent is any preoccupation with small-scale migrations that may reflect border shifts or moving population centers among seasonally transhumant groups. Environmentalist arguments have been particularly popular because they could fill out Marxist studies of economically primitive societies. ${ }^{97} \mathrm{Ar}-$ chaeologists in Eastern Europe understand migration as a one-way residential relocation to a different "environment", but they rely on general notions of the process to explain the chronological and geographic distributions of tools, ceramics, metallurgy, human biological traits, and language, and ethnicity. Migration, in other words, was used an explanatory device, and was itself only

94 See Nichols, "The linguistic geography"; Holzer, "Proto-Slavic"; Boček Pravoslovanština 2014. For an attempt at integrating the sociolinguistic approach with the historical and archaeological evidence, see Curta, "The Slavic lingua franca".

95 Urbańczyk, "Obcy wśród", pp. 70-71; "Foreign leaders", p. 263.

96 Dommelen, "Moving on", p. 480. For migration and connectivity, see Carson/Hung, "Semiconductor theory in migration".

97 Frachetti, "Migration concepts", p. 199: although the Soviet cultural-ecological approach was especially strong in the 1970s with Lev Gumilev and the integration of geological and paleoclimate research across the Soviet Union, the subtle tenor of environmentalism and primitivism survived and even flourished in post-Soviet Russia. It is important to note the accompanying lack of interest in what Carr, "A unified middle-range theory" has called "low visibility style". Archaeologists working on the Middle Ages in Eastern Europe still have to link their research questions concerning migration to their conspicuous interest in technological styles ("ways of doing things", chaînes opératoires). See Burmeister, "Archaeology and migration", p. 542; Cabana/Clark, "Migration in anthropology", p. 5; Clark, "Disappearance and diaspora", pp. 86-87 and 91. For the interest in technological styles in Eastern Europe, see Indruszewski, "Technological aspects"; Szenthe, "Technological history"; Fazioli, "Rethinking ethnicity"; Herold, "Technological traditions"; Zav'ialov/Terekhova, "Three-fold welding technology". 
rarely the subject of archaeological investigation. At the beginning of the 21st century, surrounded by the highly visible consequences of large-scale migrations, archaeologists in Eastern Europe struggle with the dissonance between the ever-increasing archaeological evidence and the complexity of the motivations for which people choose to migration, and the way they choose to do it.

\section{Bibliography}

\section{Primary Sources}

Constantine Porphyrogenitus, De administrando imperio, ed. Gy. Moravcsik/R.J.H. Jenkins (Corpus Fontium Historiae Byzantinae, 1), Washington 1967.

Jordanes, Getica, ed. Th. Mommsen, Romana et Getica (Monumenta Germaniae Historica, Auctores antiquissimi 5, 1), Berlin 1882.

Lemerle, P. (ed.), Les plus anciens recueils des Miracles de Saint Démétrius et la pénétration des Slaves dans les Balkans, Paris 1979.

Origo gentis Langobardorum, ed. G. Waitz (Monumenta Germaniae Historica, Scriptores rerum Langobardicarum et Italicarum), Hannover 1878.

Paul the Deacon, History of the Lombards, ed. G. Waitz (Monumenta Germaniae Historica, Scriptores rerum Germanicarum, 48), Hannover 1878.

Scriptor incertus, ed. F. Iadevaia, Messina 1987.

John Skylitzes, A Synopsis of Byzantine History, 811-1057, ed. H. Thurn, Berlin 1973; English translation by J. Wortley, Cambridge 2010.

\section{Secondary Literature}

Antoljak, Stjepan. "Hrvati u Karantaniji. Prilog seobi Hrvata iz Dalmacije u prekosavske krajeve u 7. stoljeću" [The Croats in Carinthia. A contribution to the history of the Croatian migration to Dalmatia from the regions beyond the Sava river (7th century)], Godishen zbornik. Filosofski fakultet na Univerzitetot Skopje 9 (1956), 15-38.

Bálint, Cs., Die Archäologie der Steppe. Steppenvölker zwischen Volga und Donau vom 6. bis zum 10. Jahrhundert, Vienna/Cologne 1989.

Bálint, Cs., "Probleme der archäologischen Forschung zur awarischen Landnahmen", in M. Müller-Wille/R. Schneider (eds.), Ausgewählte Probleme europäischer Landnahmen des Früh- und Hochmittelalters, vol. 1, Sigmaringen 1993, pp. 195-273.

Bálint, Cs., "Der Beginn der Mittelawarenzeit und die Einwanderung Kubers", Antaeus 29-30 (2008-2009), 29-61.

Balogh, Cs., "A Duna-Tisza köze avar kori betelepülése", [The settlement of the Avar population in the Danube-Tisza interfluvial region], Cumania 27 (2016), 55-74.

Barbiera, I., Changing Lands in Changing Memories. Migration and Identity during the Lombard Invasions, Florence 2005. 
Barna, F., "A magyarok útjáról az Uralról Lebediába" [The Magyar migration from the Ural Mountains to Levedia], Századok 18 (1884), 353-363, 449-456, and 527-535.

Bata, G., "The Turks who were called $\Sigma$ ABAPTOI A $\Phi$ A $\Lambda$ OI", Journal of Turkish Studies 20 (1996), 177-187.

Bierbrauer, V. “Gepiden im 5. Jahrhundert. Eine Spurensuche”, in V. Mihăilescu-Bîrliba/ C. Hriban/L. Munteanu (eds.), Miscellanea romano-barbarica. In honorem septagenarii magistri Ion Ioniţă oblata, Bucharest 2006, pp. 167-216.

Biermann, F., "Kommentar zum Aufsatz von Florin Curta: Utváření Slovanů (se zvlaštním zřetelem k Čecham a Moravě) — The Making of the Slavs (with a special emphasis on Bohemia and Moravia), Archeologické rozhledy 6o", Archeologické rozhledy 61 (2009), 337-349.

Boček, V., Pravoslovanština a jazykový kontakt [Common Slavic and language contact], Prague 2014.

Bogachev, A.V., "Problemy etnokul'turnogo vzaimodeistviia osedlykh i kochevnykh plemen Srednego Povolzh'ia v seredine I tysiacheletiia" [Problems of the ethnocultural relations between the sedentary and the nomadic populations of the Middle Volga region in the middle of the first millennium], Russian History 28 (2001), nos. 1-4, 105-136.

Bolnick, D.A., "Continuity and change in anthropological perspectives on migration. Insights from molecular anthropology", in G.S. Cabana/J.J. Clark (eds.), Rethinking Anthropological Perspectives on Migration, Gainesville, 2011, pp. 263-277.

Bóna, I., "Die Geschichte der Awaren im Lichte der archäologischen Quellen", in Popoli delle steppe: Unni, Avari, Ungari, Spoleto 1988, pp. 440-458.

Borgolte, M., "Eine langobardische 'Wanderlawine” vom Jahr 568 ? Zur Kritik historiographischer Zeugnisse der Migrationsperiode", Zeitschrift für Geschichtswissenschaft 61 (2013), 293-310.

Borkovský, I., Staroslovanská keramika ve střední Evropě. Studie k počátkům slovanské kultury [The oldest Slavic pottery of central Europe]), Prague 1940.

Borovszky, S. "A longobardok vándorlása” [The Lombard migration], Századok 19 (1885), 501-518, 590-602, 662-676, and 725-736.

Borri, F., "White Croatia and the arrival of the Croats: an interpretation of Constantine Porphyrogenitus on the oldest Dalmatian history", Early Medieval Europe 19/2 (2011), 204-231.

Brather, S., "Einwanderergruppe oder Regionalentwicklung? Die frühen Slawen zwischen Elbe und Oder", Das Altertum 45 (1999), 301-316.

Brather, S., Archäologie der westlichen Slawen. Siedlung, Wirtschaft und Gesellschaft im früh- und hochmittelalterlichen Ostmitteleuropa (Ergänzungsbände zum Reallexikon der Germanischen Altertumskunde, 30), Berlin/New York 2001.

Brătianu, Gh.I., "Bulgaria de dincolo de Dunăre' în izvoarele bizantine” ["Bulgaria beyond the Danube" in the Byzantine sources], in Omagiu lui I. Lupaş la împlinirea vârstei de 6o ani, august 1940, Bucharest 1943, pp. 127-132. 
Bubenok, O.B., "Savarty-asfaly v 'kraiakh Persii': pravda ili vymysel?" [The "Sabartoi asphaloi" in the "region of Persia": truth or fabrication?], in E.A. Mel'nikova/T.M. Kalinina/A.S. Shchavelev (eds.), Vostochnaia Evropa v drevnosti i srednevekov'e. Migracii, rasselenie, voina kak faktory politogeneza. xxiv Chteniia pamiati chlena-korrespondenta AN SSSR Vladimira Terent'evicha Pashuto. Moskva, 18-20 aprelia 2012. Materialy konferencii, Moscow 2012, pp. 30-34.

Burmeister, S., "Archaeology and migration. Approaches to an archaeological proof of migration", Current Anthropology 41/4 (2000), 539-567.

Bystrický, P., Stáahovanie národov (454-568). Ostrogóti, Gepidi, Longobardi a Slovania [The Migration Period (454-568). Ostrogoths, Gepids, Lombards, and Slavs], Bratislava 2008.

Cabana, G.S./Clark, J.J., "Migration in anthropology. Where we stand”, in G.S. Cabana/J.J. Clark (eds.), Rethinking Anthropological Perspectives on Migration, Gainesville 2011, pp. $3^{-15}$.

Canache, A./Curta, F., "Depozite de unelte şi arme medievale timpurii de pe teritoriul României" [Hoards of early medieval iron weapons and implements in Romania], Mousaios 4/1 (1994), 179-221.

Carr, C., "A unified middle-range theory of artifact design", in C. Carr/J.E. Neitzel (eds.), Style, Society, and Person: Archaeological and Ethnological Perspectives, New York/ London 1995, pp. 171-258.

Carson, M.T./Hung, H., "Semiconductor theory in migration: population receivers, homelands, and gateways in Taiwan and Island Southeast Asia", World Archaeology 46/4 (2014), 502-515.

Ciupercă, B., "Some observations from the point of view of the Slon fortifications about power centres in the Lower Danube between the eighth and the tenth centuries", in A. Paron'/S. Rossignol/B.S. Szmoniewski/G. Vercamer (eds.), Potestas et communitas. Interdisziplinäre Beiträge zu Wesen und Darstellung von Herrschaftsverhältnissen im Mittelalter östlich der Elbe, Warsaw/Wrocław 2010, pp. 257-289.

Clark, J.J., "Disappearance and diaspora. Contrasting two migrations in the southern U.S. Southwest”, in G.S. Cabana/J.J. Clark (eds.), Rethinking Anthropological Perspectives on Migration, Gainesville 2011, pp. 84-107.

Curta, F., The Making of the Slavs. History and Archaeology of the Lower Danube Region, c. 500-70o, Cambridge/New York 2001.

Curta, F., "The Prague type: a critical approach to pottery classification", Archaeologia Bulgarica 5/1 (2001), 73-106.

Curta, F., "The Slavic lingua franca (Linguistic notes of an archaeologist turned historian)", East Central Europe 31/1 (2004), 125-148.

Curta, F., "The earliest Avar-age stirrups, or the 'stirrup controversy' revisited", in F. Curta (ed.), The Other Europe in the Middle Ages. Avars, Bulgars, Khazars, and 
Cumans (East Central and Eastern Europe in the Middle Ages, 450-1450, 2), Leiden/ Boston 2008, pp. 297-326.

Curta, F., "Utváření Slovanů (se zvláštním zřetelem k Čechám a Moravě)" [The making of the Slavs (with a special emphasis on Bohemia and Moravia)], Archeologické rozhledy 60 (2008), 643-694.

Curta, F., Text, Context, History, and Archaeology. Studies in Late Antiquity and the Middle Ages (Florilegium magistrorum historiae archaeologiaeque Antiquitatis et Medii Aevi, 6), Bucharest/Brăila 2009.

Curta, F., "The early Slavs in Bohemia and Moravia: a response to my critics", Archeologické rozhledy 61 (2009), 725-754.

Curta, F., "The early Slavs in the northern and eastern Adriatic region. A critical approach", Archeologia Medievale 37 (2010), 307-329.

Curta, F., "The beginning of the Middle Ages in the Balkans", Millennium 10 (2013), $145^{-214}$.

Curta, F., "The image and archaeology of the Pechenegs", Banatica 23 (2013), 143-202.

Curta, F., "Four questions for those who still believe in prehistoric Slavs and other fairy tales", Starohrvatska prosvjeta 42 (2015), 286-303.

Darkó, Jenő. "Die Übersiedlung der Walachen vom Süden nach Norden der Donau”, Izvestiia na Bălgarskoto istorichesko druzhestvo 17 (1940), 173-180.

Dienes, I., “A karancslapujtői honfoglalás kori őv és mordvinföldi hasonmása” [The belt set from Karancslapujtő dated to the 1oth century and its analogy from the land of the Mordva], Archaeologiai Értesitô 91 (1964), 18-40.

Dienes, I., Die Ungarn um die Zeit der Landnahme, Budapest 1972.

Dommelen, P. van, "Moving on: archaeological perspectives on mobility and migration", World Archaeology 46/4 (2014), 477-483.

Ducellier, A., "Les sources byzantines et l'apparition des Hongrois en Europe", Etudes finno-ougriennes 1 (1964), 29-53.

Ducellier, A., "Les Albanais du XIe au XıIIe siècle: nomades ou sédentaires?” Byzantinische Forschungen 7 (1979), 23-36.

Dudek, J., "Pieczęć magistra Jana Kegena jako wyraz polityki Bizancjum wobec stepowców w połowie XI w". [The seal of magistros John Kegen as an expression of the Byzantine empire's policy towards nomads in the mid-11th century], in S. Rosik/P. Wiszewski (eds.), Causa creandi. O pragmatyce źródta historycznego, Wrocław 2005, pp. 327-343.

Dulinicz, M., "Najstarsza faza osadnictwa słowiańskiego w północnej części Europy Środkowej" [The earliest phase of the Slavic migration to the northern part of Central Europe], in P. Kaczanowski/M. Parczewski (eds.), Archeologia o początkach Stowian. Materiaty z konferencji, Kraków, 19-21 listopada 2001, Cracow 2005, pp. $513-526$. 
Dulinicz, M., Frühe Slawen im Gebiet zwischen unterer Weichsel und Elbe. Eine archäologische Studie, Neumünster 2006.

Dzino, D., Becoming Slav, Becoming Croat. Identity Transformation in Post-Roman and Early Medieval Dalmatia (East Central and Eastern Europe in the Middle Ages, 4501450, 12), Leiden/Boston 2010.

Dzino, D., "Pričam ti priču: ideološko-narativni diskursi o dolasku Hrvata u De administrando imperio" [Telling the stories: ideological-narrative discourses on the Croat migrations in De administrando imperio], Radovi Zavoda za hrvatsku povijest 42 (2010), 153-165.

Fazioli, K.P., "Rethinking ethnicity in early medieval archaeology: social identity, technological choice, and communities of practice", in S.D. Stull (ed.), From West to East. Current Approaches to Medieval Archaeology, Newcastle upon Tyne 2014, pp. 20-39.

Fiedler, U., "Bulgars in the Lower Danube region. A survey of the archaeological evidence and of the state of current research", in F. Curta (ed.), The Other Europe in the Middle Ages. Avars, Bulgars, Khazars, and Cumans, Leiden/Boston 2008, pp. $15^{1-236 .}$

Fiedler, U., "Zur Suche nach dem archäologischen Niederschlag von Petschenegen, Uzen und Kumanen in den Gebieten südlich der unteren Donau”, in F. Curta/B.-P. Maleon (eds.), The Steppe Lands and the World Beyond Them. Studies in Honor of Victor Spinei on his 7oth Birthday, Iași 2013, pp. 249-285.

Fodor, I., In Search of a New Homeland. The Prehistory of the Hungarian People and the Conquest. Budapest 1982.

Fodor, I., "K voprosu ob etnicheskoi prinadlezhnosti imen'kovskoi kul'tury (Tezisy)" [On the ethnic attribution of the Imen'kovo culture], in M.Z. Vasiutin (ed.), Formirovanie, istoricheskoe vzaimodeistvie, kul'turnye sviazi finno-ugorskikh narodov. Materialy III mezhdunarodnogo istoricheskogo kongressa finno-ugrovedov, IoshkarOla 2004, pp. 106-107.

Fodor, I., "Ecology and migrations on the Eurasian steppes and the Carpathian Basin", Chronica. Annual of the Institute of History, University of Szeged 7-8 (2007-2008), $77-84$.

Fodor, I., “A 'kettős honfoglalás' elméletének forrásvidéke" [The sources of the "double land-taking" theory], Korunk 8 (2014), 75-81.

Fóthi, E./Lőrinczy, G./Marcsik, A., "Arkheologicheskie i antropologicheskie sviazi mezhdu stepiami Evrazii i ranneavarskoi gruppoi naseleniia v Karpatskom basseine" [Archaeological and anthropological relations between the Eurasian steppe and a group of early Avar population in the Carpathian Basin], in D.A. Stashenkov/A.F. Kochkina/A.M. Kuznecova (eds.), Kul'tury evraziiskikh stepei vtoroi poloviny I tysiacheletiia n.e. (iz istorii kostiuma), vol. 2, Samara 2001, pp. 211-219.

Frachetti, M., "Migration concepts in Central Eurasian archaeology", Annual Review of Anthropology 40 (2011), 195-212. 
Freeden, U. von, “Wer stört Gräber? Grabstörungen ohne Graböffnungen”, Acta Archaeologica Academiae Scientiarum Hungaricae 59 (2008), no. 2, 247-255.

Freeden, U. von/Vida, T., "Ausgrabung des langobardenzeitlichen Gräberfeldes von Szólád, Komitat Somogy, Ungarn. Vorbericht und Überblick über langobardenzeitlichen Besiedlung am Plattensee", Germania 85 (2005), 359-384.

Friedwagner, M. "Über die Sprache und Heimat der Rumänen in ihre Frühzeit", Zeitschrift für romanische Philologie 44 (1934), 641-715.

Furas'ev, A.G., "Fenomen kievskoi arkheologicheskoi kul'tury i ranneslavianskoe edinstvo", [The phenomenon of the Kiev archaeological culture and the early Slavic unity], in D.A. Machinskii (ed.), Istoki slavianstva i Rusi. Sbornik statei po materialam X chtenii pamiati Anny Machinskoi (Staraia Ladoga, 24-25 dekabria 2005 g.), St. Petersburg 2012, pp. 166-174.

Fusek, G., "Drevnee slavianskoe naselenie na territorii Slovakii" [The early Slavic population on the territory of Slovakia], Stratum + (2015), 5, 151-62.

Garam, É. "The Vrap treasure”, in K. Reynolds Brown/D. Kidd/Ch.T. Little (eds.), From Attila to Charlemagne. Arts of the Early Medieval Period in the Metropolitan Museum of Art, New York 200o, pp. 170-179.

Gardeła, L. Scandinavian Amulets in Viking Age Poland, Rzeszów 2014.

Gardeła, L., "Amulety skandynawskie z Wolina i Truso" [Scandinavian amulets from Wolin and Truso], in J. Popielska-Grzybowska/J. Iwaszczuk (eds.), Meetings at the Borders. Studies Dedicated to Professor Wtadystaw Duczko, Pułtusk 2016, pp. 99-106.

Gavritukhin, I.O., "Nachalo velikogo slavianskogo rasselenie na iug i zapad" [The beginning of the Slavic migration to the south and west], in P.P. Tolochko (ed.), Arkheologichni studii, vol. 1, Kiev/Chernivtsi 200o, pp. 72-90.

Godłowski, K., "Die Frage der slawischen Einwanderung in östliche Mitteleuropa", Zeitschrift für Ostforschung 28 (1979), 416-447.

Godłowski, K., Frühe Slawen in Mitteleuropa, Neumünster 2005.

Goffart, W., Barbarian Tides. The Migration Age and the Later Roman Empire, Philadelphia 2006.

Gołębiowska-Tobiasz, A., "The Hungarians in the era of formation of south-western borders of the Rurik state. Notes on ethnogenesis of old Hungarians", in V. Nagirnyy/A. Mesiarkin (eds.), Rus' and Central Europe from the 11th to the 14th Century. Publication after the 5th International Conference, Spišská kapitula, 16th-18th October, 2014, Cracow/Bratislava 2015, pp. 37-54.

Gulyás, B., "Újabb adatok a kora avar kori Tiszántúl kelet-európai kapcsolataihoz" [New results of the research concerning the relations between Eastern Hungary and the East European steppe lands in the Early Avar period], in Cs. Balogh/B. Major (eds.), Hadak útján XXIV. A népvándorláskor fiatal kutatóinak XXIV. konferenciája. Esztergom, 2014. november 4-6., vol. 1, Budapest/Esztergom 2015, pp. 499-512. 
Halsall, G., Barbarian Migrations and the Roman West, 376-568, Cambridge/New York 2007 .

Hauptmann, L., "Dolazak Hrvata" [The Croatian conquest of Dalmatia], in Zbornik kralja Tomislava u spomen tisučugodišnjice hrvatskogo kraljevstva, Zagreb 1925, pp. 86-127.

Heather, P., The Goths, Oxford 1996.

Heather, P., Empires and Barbarians, London 2009.

Heinrich-Tamáska, O./Schweissing, M., "Strontiumisotopen- und Radiokarbonuntersuchungen am anthropologischen Fundmaterial von Keszthely-Fenékpuszta: ihr Aussagepotenzial zur Fragen der Migration und Chronologie”, in O. HeinrichTamáska (ed.), Keszthely-Fenékpuszta im Kontext spätantiker Kontinuitätsforschung zwischen Noricum und Moesia, Budapest/Leipzig/Keszthely/ Rahden 2011, pp. $457-474$.

Herold, H., "Technological traditions in early medieval eastern Austria”, in O. HeinrichTamáska/P. Straub/T. Vida (eds.), “Castellum, civitas, urbs”. Zentren und Eliten im frühmittelalterlichen Ostmitteleuropa, Rahden 2015, pp. 329-344.

Holzer, G., "Proto-Slavic: historical setting and linguistic reconstruction", East Central Europe 31 (2004), no. 1, 49-59.

Indruszewski, G., "Technological aspects of cultural identity: the case of early medieval shipbuilding and seafaring in the Baltic", in S. Moździoch/B. Stanisławski/P. Wiszewski (eds.), Scandinavian Culture in Medieval Poland, Wrocław 2013, pp. 437-455.

Iordanov, I., "Sceau d'archonte de Patzinakia du XI-e siècle", Etudes Balkaniques 28/2 (1992), 79-82.

Iordanov, I., "Pechati na Ioan Kegen, magistăr i arkhont na Pechenegiia (1050-1051)" [The seal of John Kegen, the magistros and archon of Patzinakia, 1050-1051], Numizmatika i sfragistika 5/1 (1998), 96-101.

Iushkova, M.A., "North-western Russia before its settling by Slavs (8th century BC-8th century AD)", in J. Nuorluoto (ed.), The Slavicization of the Russian North. Mechanisms and Chronology, Helsinki 2006, pp. 141-154.

Ivanov, R., "Novi danni za pechenegite v Iuzhna Dobrudzha" [New data on the Pechenegs in southern Dobrudzha], Dobrudzha 30 (2015), 401-410.

Jansson, I., "Warfare, trade or colonisation? Some general remarks on the eastern expansion of the Scandinavians in the Viking period", in P. Hansson (ed.), The Rural Viking in Russia and Sweden. Conference 19-20 October 1996 in the Manor of Karlslund, Örebro, Sweden, Örebro 1997, pp. 9-64.

Jarak, M., "Zapažanja o grobljima 8.i 9. st. u Dalmaciji” [Notes on the cemeteries of the 8th and 9th century in Dalmatia], Opuscula Archaeologica 26 (2002), 247-255.

Jarnut, J., Die Geschichte der Langobarden, Stuttgart 1982.

Kardaras, G., "The settlement of the Croats and Serbs on the Balkans in the frame of the Byzantine-Avar conflicts", in S. Dermendzhieva/D. Dimitrov (eds.), Bălgariia, bălgarite i Evropa. Mit, istoriia, săvremie. IV (Dokladi ot Mezhdunarodna konferenciia 
v pamet na prof. d.i.n. Iordan Andreev “Bălgariia, zemia na blazheni...”, V. Tărnovo, 29-31 oktomvri 2009 g.), Veliko Tărnovo 2011, pp. 91-98.

Kazanski, M., "Les Slaves dans la zone forestière d'Europe orientale au début du Moyen Age” in M. Kazanski/A. Nercessian/C. Zuckerman (eds.), Les centres proto-urbains russes entre Scandinavie, Byzance et Orient. Actes du colloque international tenu au Collège de France en octobre 1997, Paris 2000, pp. 17-44.

Keresztes, N.N., "Fegyveres langobardok Magyarországon I. Típusok és fegyverkombinációk" [Langobard warriors in Hungary I. Types and combinations], in Cs. Balogh/B. Major (eds.), Hadak útján XXIV. A népvándorláskor fiatal kutatóinak XXIV. konferenciája. Esztergom, 2014. november 4-6., vol. 1, Budapest/Esztergom 2015, pp. 469-498.

Klein, L.S., "Migraciia: arkheologicheskie priznaki" [The archaeological markers of migration], Stratum+ (1999), 1, 151-62.

Knudson, K., "Identifying archaeological human migration using biogeochemistry. Case studies from the south-central Andes", in G.S. Cabana/J.J. Clark (eds.), Rethinking Anthropological Perspectives on Migration, Gainesville, 2011, pp. 231-247.

Kobyliński, Z., “The Slavs, 500-700 A.D.", in P. Fouracre (ed.), The New Cambridge Medieval History, vol. 1, Cambridge/New York 2005, pp. 524-544.

Koneckii, V. Ia., "Slavianskaia kolonizaciia Iuzhnogo Prichud'ia na fone obshchikh etnokul'turnykh processov Severo-Zapada" [The Slavic colonization of the southern region of Lake Peipus against the background of the ethno-cultural processes in Northwestern Russia], in V.V. Sedov (ed.), Pskov v rossiiskoi i evropeiskoi istorii. $K$ 110o-letiiu pervogo letopisnogo upominaniia, Moscow 2003, pp. 206-212.

Kristiansen, K./Šmejda, L./Turek, J., "Evžen Neustupný: paradigm found", in K. Kristiansen/L. Šmejda/J. Turek (eds.), Paradigm Found. Archaeological Theory, Present, Past and Future. Essays in Honour of Evžen Neustupný, Oxford/Philadelphia 2014, pp. 1-4.

Kristó, Gy., "Nyelv és etnikum. A 'kettős honfoglalás' elméleti alaplaihoz" [Language and ethnicity. On the theoretical basis of the "double conquest" concept], in A. Róna-Tas (ed.), A 8o-as évek társadalomtudománya: eredmények és perspektivák, Szeged 1983, pp. 177-190.

Kulikowski, M., Rome's Gothic Wars from the Third Century to Alaric, Cambridge/New York 2007.

Kuna, M., "Intransigent archaeology. An interview with Evžen Neustupný on his life in archaeology", Archaeological Dialogues 19/1 (2012), 3-28.

Kunstmann, H., "Wie die Slovene an den Ilmensee kamen”, Welt der Slawen 30 (1985), 387-401.

Kunstmann, H., "Waren die ersten Přemysliden Balkanslaven?", Welt der Slawen 32 (1987), 25-47.

Kuz'min, S.L., “O vremeni, kharatere i obstaiatel'stvakh slavianskogo rasseleniia na Severo-Zapade" [On the chronology, character, and circumstances of the Slavic 
settlement in northwestern Russia], in D.A. Machinskii (ed.), Ladoga i epokha vikingov. Chetvertye chteniia pamiati Anny Machinskoi. Staraia Ladoga, 21-23 dekabria 1198 g. Materialy k chteniiam, St. Petersburg 1998, pp. 8-15.

Kuz'min, S.L./Mikhailova, E.R., "Novye materialy k probleme slavianskogo rasseleniia na severo-zapade Rusi" [New data on the problem of the Slavic settlement in northwestern Russia], in V.V. Sedov (ed.), Etnogenez i etnokul'turnye kontakty slavian (Trudy vi Mezhdunarodnogo Kongressa slavianskogo arkheologii, 3), Moscow 1997, pp. 138-146.

La Salvia, V., "La diffusione della staffa nell'area merovingia orientale alla luce delle fonti archeologiche", Temporis signa. Archeologia della tarda antichità e del medioevo 2 (2007), 155-171.

Langó, P., "Archaeological research on the conquering Hungarians: a review", in B.G. Mende (ed.), Research on the Prehistory of the Hungarian: a Review. Papers Presented at the Meetings of the Institute of Archaeology of the HAS, 2003-2004, Budapest 2005, pp. $175^{-340 .}$

László, Gy., "A 'kettős honfoglalás'-ról" [On the Magyar "double conquest”], Archaeologiai Értesitő 97 (1970), 161-190.

Leach, S., A Russian Perspective on Theoretical Archaeology. The Life and Work of Leo S. Klejn, Walnut Creek 2015.

Lőrinczy, G., "Kelet-európai steppei népesség a 6-7. századi Kárpát-medencében. Régészeti adatok a Tiszántúl kora avar kori betelepüléséhez" [The East European steppe population in the Carpathian Basin during the 6th and 7 th centuries. Archaeological contributions to the Early Avar settlement in the lands beyond the Tisza], Móra Ferenc Múzeum Evkönyve. Studia Archaeologica 4 (1998), 343-472.

Macdonald, J.S./Macdonald, L.D., "Chain migration, ethnic neighborhood formation and social networks", Millbank Memorial Fund Quarterly 42/1 (1964), 82-97.

Machinskii, D.A., "Migraciia slavian v I tysiacheletiia n. e". [The migration of the Slavs in the first millennium], in V.D. Koroliuk (ed.), Formirovanie rannefeodal'nykh slavianskikh narodnostei, Moscow 1981, pp. 31-52.

Madaras, L., “Az Alföldi avarság 9. századi továbbélésének lehetoségérol a régészeti források tükrében" [The presumed continuity of the Avar population in the 9th-century Great Plain in the light of the archaeological evidence], in G. Lőrinczy (ed.), $A z$ Alföld a 9. században (Az 1992. November 30-December 1-én elhangzott előadások írott változatai), Szeged 1993, pp. 11-32.

Madgearu, A., “The periphery against the centre: the case of Paradunavon", Zbornik radova Vizantološkog Instituta 40 (2003), 49-56.

Magyar, K., "A honfoglalás (kettős honfoglalás) legújabb somogyi forrásairól" [The newest evidence of the conquest (double conquest) of the homeland from Co. Somogyi], Valóság 39/6 (1996), 42-53. 
Malyarchuk, B.A./Grzybowski, T./Derenko, M.V./Czarny, J./Drobnič, K./MiścickaŚliwka, D., "Mitochondrial DNA variability in Bosnians and Slovenians", Annals of Human Genetics 67/5 (2003), 412-425.

Matveeva, G.I., "O proiskhozhdenii imen'kovskoi kul'tury" [On the origin of the Imen'kovo culture], in G.I. Matveeva (ed.), Drevnie i srednevekovie kul'tury Povolzh'ia. Mezhvuzovskii sbornik, Kuibyshev 1981, pp. 52-73.

Matveeva, G.I., "K voprosu o proiskhozhdenii pogrebenii s trupopolozheniiami na territorii imen'kovskoi kul'tury" [On the origin of inhumation burials from the Imen'kovo culture], in A.F. Kochkina/L.V. Kuznecova/D.A. Stashenkov (eds.), Kul'tury evraziiskikh stepei vtoroi poloviny I tysiacheletiia n.e, Samara 1996, pp. 58-65.

Matveeva, G.I., Srednee Povolzh'e v IV-VII vv.: imen'kovskaia kul'tura [The Middle Volga region between the 4th and the 7 th cc.: the Imen'kovo culture], Samara 2003.

Měřínský, Z., České země od př́chodu Slovanů po Velkou Moravu [The Czech lands from the arrival of the Slavs to Great Moravia], Prague 2002.

Mesterházy, K., "Die Landnahme der Ungarn aus archäologischer Sicht”, in M. MüllerWille/R. Schneider (eds.), Ausgewählte Probleme europäischer Landnahmen des Früh- und Hochmittelalters, vol. 2, Sigmaringen 1994, pp. 22-65.

Mielnik-Sikorska, M./Daca, P./Malyarchuk, B.A./Derenko, M.V./Skonieczna, K./Perkova, M.A./Dobosz, T./Grzybowski, T., "The history of the Slavs inferred from complete mitochondrial genome sequences", PLoS One 8 (2013), 1-11.

Minasian, R.S., "Problema slavianskogo zaseleniia lesnoi zony Vostochnoi Evropy v svete arkheologicheskikh dannykh" [Problems of the Slavic settlement of the forest belt in Eastern Europe in the light of the archaeological evidence], in A.D. Stoliar (ed.), Severnaia Rus' i ee sosedi v epokhu rannego srednevekov'ia. Mezhvuzovskii sbornik, Leningrad 1982, pp. 24-29.

Múcska, V. "Migracja i etnogeneza węgrów. Zarys współczesnego stanu badań” [The migration and ethnogenesis of the Hungarians. An outline of contemporary research], in M. Salamon/J. Strzelczyk (eds.), Wędrówka i etnogeneza w starożytności i średniowieczu, Cracow 2010, pp. 335-347.

Musset, L., Les invasions: le second assaut contre l'Europe chrétienne (VII-e-XI-e siècles). Paris 1971.

Neustupný, E., "Prehistoric migrations by infiltration”, Archeologické rozhledy 34 (1982), 278-293.

Nichols, J., "The linguistic geography of the Slavic expansion", in R.A. Maguire/A. Timberlake (eds.), American Contributions to the Eleventh International Congress of Slavists. Bratislava, August-September 1993. Literature, Linguistics, Poetics, Columbus 1993, pp. 377-391.

Novikova, G.L., "Iron neck-rings with Thor's hammers found in Eastern Europe", Fornvännen 87 (1992), 73-89. 
Nowakowski, W., "Die Olsztyn-Gruppe (masurgermanische Kultur) in der Völkerwanderungszeit. Das Problem ihrer chronologischen und territorialen Grenzen”, in M. Maczyńska/T. Grabarczyk (eds.), Die spätrömische Kaiserzeit und die frühe Völkerwanderungszeit im Mittel- und Osteuropa, Łódż 200o, pp. 168-19o.

Nowakowski, W., "Zmierzch dawnych czasów, czy świt nowej epoki? Południowa rubież osadnictwa zachodniobałtyskiego w VI-VII wieku" [The twilight of the old times or the dawn of the new epoch? The southern outskirts of the West Baltic settlement area in the 6th and 7 th century], in W. Chudziak/S. Moździoch (eds.), Stan i potrzeby badań nad wczesnym średniowieczem $w$ Polsce-15 lat później, Toruń/ Wrocław/Warsaw 2006, pp. 273-283.

Okulicz, J., "Osadnictwo ziem pruskich od czasów najdawniejszych do XIII wieku" [The settlement in Prussia from the earliest times to the 13th c.], in J. Sikorski/S. Szostakowski (eds.), Dzieje Warmii i Mazur w zarysie, vol. 1, Warsaw 1981, pp. 8-6o.

Olajos, T., "De la théorie de la 'double conquête' hongroise du Bassin des Carpathes", Studia Hungaro-Bulgarica 1 (2007), 49-61.

Oleinikov, O.M., "Kul'tura dlinnykh kurganov verkhnevolzhskogo i verkhnedneprovskogo regionov" [The culture of the long barrows in the Upper Volga and Upper Dnieper regions], Tverskoi Arkheologicheskii Sbornik 6/2 (2007), 166-184.

Ovchinnikova, B.B./Gyóni, G., Protovengry na Urale v trudakh rossiskikh i vengerskikh issledovatelei [The Proto-Hungarians in the Urals in the Russian and Hungarian historiography], Ekaterinburg 2008.

Peters, D./Knipper, C./ von Freeden, U./Müller, W./Maurer, A.-F./Alt, K.W./Vida, T., 'Schmelztiegel Balaton? Zum Verhältnis 'langobardischer' Einwanderergruppen und (vor-)langobardenzeitlichen romanischer Bevölkerung am Balaton-Szólád und Keszthely-Fenékpuszta zwischen Archäologie und Isotopie", in O. HeinrichTamáska/P. Straub (eds.), Mensch, Siedlung und Landschaft im Wechsel der Jahrtausende am Balaton, Budapest/Leipzig/Keszthely/Rahden 2014, pp. 337-360.

Piguet-Panayotova, D., "The gold and silver vessels from the Albanian treasure in a new light”, in R. Harreither/Ph. Pergola/R. Pillinger/A. Pülz (eds.), Acta Congressus internationalis XIV archaeologiae Christianae, Vindobonae 19.-26. 9. 1999. Frühes Christentum zwischen Rom un Konstantinopel, Vatican 2006, pp. 6o9-619.

Pillon, M., "L'exode des Sermésiens et les grandes migrations des Romains de Pannonie dans les Balkans durant le Haut Moyen Age", Etudes Balkaniques 38/3 (2002), 103-141.

Pleterski, A., Etnogeneza Slovanov: obris trenutnega stanja arheoloskih raziskav [The ethnogenesis of the Slavs. An outline of the current state of archaeological research], Ljubljana 1990.

Pleterski, A., "Etnogeneza Slavena-metode i proces", [The Slavic ethnogenesismethod and process], Starohrvatska prosvjeta 40 (2013), 8-32.

Pohl, W., Die Awaren. Ein Steppenvolk im Mitteleuropa 567-822 n. Chr., Munich 2002. 
Pohl, W., "Migration und Ethnogenese der Langobarden aus Sicht der Schriftquellen", in J. Bemmann/M. Schmauder (eds.), Kulturwandel in Mitteleuropa. LangobardenAwaren-Slawen. Akten der internationalen Tagung in Bonn vom 25. bis 28 Februar 2008, Bonn 2008, pp. 1-12.

Price, T.D./Frei, K.M., "Isotopic proveniencing of the Bodzia burials", in A. Buko (ed.), Bodzia. A Late Viking-Age Elite Cemetery in Central Poland (East Central and Eastern Europe in the Middle Ages, 450-1450, 27), Leiden/Boston 2015, pp. 445-462.

Profantová, N., "Cultural discontinuity and the migration hypothesis. The 'Slavic migration' (6th century) in the light of new archaeological finds from Bohemia", in R. Annaert/T. Jacobs/I. In't Ven/S. Coppens (eds.), The Very Beginning of Europe? Cultural and Social Dimensions of Early Medieval Migration and Colonisation (5th-8th Century). Archaeology in Contemporary Europe. Conference, Brussels, May 17-19, 2011, Brussels 2012, pp. 255-264.

Profantová, N., "Slaviane na territorii Chekhii i ikh kontakty v VI-VII vv". [Slavs on the territory of Czechia and their contacts in the 6th-7th centuries], Stratum + (2015), 5 , 97-116.

Profantová, N./Bureš, M., "Bedeutende frühe slawische Siedlungen in Böhmen (6.-8. Jh.) und Probleme der absoluten Datenerfassung”, in M. Dulinicz/S. Moździoch (eds.), The Early Slavic Settlement in Central Europe in the Light of New Dating Evidence, Wrocław 2013, pp. 169-194.

Prykhodniuk, O.M., "Osnovni pidsumky ta zavdannia vyvchennia Pastyrs'kogo gorodyshcha", [The main results and the main problems of the archaeological excavations within the Pastyr stronghold], Arkheolohiia 3 (1998), 4-24.

Pylypchuk, Ia., "Predystoriia vengrov i vengero-permskaia problema" [The prehistory of the Magyars and the Magyar-Perm problem], Ekho vekov 1-2 (2015), 121-132.

Rastoropov, A.V., “Voprosy etnokul'turnoi istorii lesostepnoi Povolzh'ia vtoroi poloviny I tysiacheletiia n. e. i migracii naseleniia" [Questions of ethnohistory regarding the forest-steppe belt in the Volga region during the second half of the first millennium $\mathrm{AD}$ and the migration of the population], in D.A. Stashenkov (ed.), Kul'tury evraziiskikh stepei vtoroipoloviny I tysiacheletiia n. e. Voprosy mezhetnicheskikh kontaktov i mezhkul'turnogo vzaimodeistviia, Samara 2010, pp. 45-49.

Róna-Tas, A., "The migration of the Hungarians and their settlement in the Carpathian basin", in A. Berta/E. Horváth (eds.), Historical and Linguistic Interaction Between Inner Asia and Europe. Proceedings of the 39th Permanent International Altaistic Conference (PIAC), Szeged, Hungary: June 16-21, 1996, Szeged 1997, pp. 243-253.

Schramm, G., Eroberer und Eingesessene. Geographische Lehnnahmen als Zeugen der Geschichte Südosteuropas im ersten Jahrtausend n.Chr., Stuttgart 1981.

Schramm, G., Anfänge des albanischen Christentums. Die frühe Bekehrung der Bessen und ihre langen Folgen, Freiburg im Breisgau 1994.

Schweissing, M.M., "Archäologische Fragen zu Migration: Grundlagen, Chancen und Probleme von Untersuchungen stabiler Strontiumisotope $\left({ }^{87} \mathrm{Sr} /{ }^{86} \mathrm{Sr}\right)$ ", in $\mathrm{O}$. 
Heinrich-Tamáska/N. Krohn/S. Ristow (eds.), Dunkle Jahrhunderte in Mitteleuropa? Tagungsbeiträge der Arbeitsgemeinschaft Spätantike und Frühmittelalter. 1. Rituale und Moden (Xanten, 8. Juni 2006). 2. Möglichkeiten und Probleme archäologischnaturwissenschaftlicher Zusammenarbeit (Schleswig, 9.-10. Oktober 2007)(Studien zu Spätantike und Frühmittelalter, 1), Hamburg 2009, pp. 293-306.

Sedov, V.V., "Nachalo slavianskogo osvoeniia territorii Novgorodskoi zemli" [The beginning of the Slavic settlement of the Novogorod lands], in G.A. Fedorov-Davydov/ E.A. Ryvina/A.S. Khoroshev (eds.), Istoriia i kul'tura drevnerusskogo goroda, Moscow 1989, pp. 12-17.

Sedov, V.V., "Venedy-slaviane v Iugo-Vostochnoi Pribaltike", [Venedi-Slavs on the southeastern shore of the Baltic Sea], Arkheologiia i istoriia Pskova i Pskovskoi zemli (1992), 35-37.

Sedov, V.V., Slaviane v drevnosti [The Slavs in the past], Moscow 1994.

Sedov, V.V., "Proiskhozhdenie slavian i mestonakhozhdenie ikh prarodiny. Rasselenie slavian v V-VII vv." [The origin of the Slavs and their native land. Settling apart of the Slavs in the $5^{\text {th }}-7_{\text {th }}$ c.) ], in V.K. Volkov/V. Ia. Petrukhin/S.M. Tolstaia/B.N. Flor'ia (eds.), Ocherki istorii kul'tury slavian, Moscow 1996, pp. 15-115.

Sedov, V.V., "O rasselenii dunaiskikh slavian na Vostochnoevropeiskoi ravnine" [The migration of the Danubian Slavs to the East European plains], in E.A. Mel'nikova (ed.), Vostochnaia Evropa v drevnosti i srednevekov'e. Kontakty, zony kontaktov i kontaktnye zony. XI Chteniia pamiati chlena-korrespondenta AH SSSR Vladimira Terent'evicha Pashuto, Moskva, 14-16 aprelia 1999 g., Moscow 1999, pp. 39-41.

Sedov, V.V., "Migraciia dunaiskikh slavian v Vostochnuiu Evropu" [The migration of the Danubian Slavs to Eastern Europe], Arkheologiia i istoriia Pskova i Pskovskoi zemli (2000), 160-165.

Sedov, V.V., "Osnovnye voprosy izucheniia tushemlinskoi kul'tury" [The main issues in the study of the Tushemlia culture], Stratum + (2001-2002), 6, 431-437.

Sedov, V.V., "Sever Vostochno-Evropeiskoi ravniny v period pereseleniia narodov i v rannem srednevekov'e (predyistoriia severnovelikorusov)", [The northern part of Eastern Europe during the Great Migration period and the early Middle Ages (the prehistory of the northern Russians)], Kratkie soobshcheniia Instituta Arkheologii AN Rossii 218 (2005), 12-22.

Shcheglova, O.A., "Volny rasprostraneniia veshchei iz Podunav'ia na Severo-Vostok v VI-VIII vv. kak otrazhenie migracii ili kul'turnykh vliianii" [The spread of artifacts from the Danube region to northeastern Russia in the 6th to 8th centuries as indication of migration or cultural contacts], in D.A. Machinskii/T.B. Senichenkova (eds.), Slozhenie russkoi gosudarstvennosti $v$ kontekste rannesrednevekovoi istorii Starogo Sveta. Materialy mezhdunarodnoi konferencii, sostoiavsheisia 14-18 maia 2007 godav Gosudarstvennoi Ermitazhe, St. Petersburg 2009, pp. 39-65. 
Shevchenko, Iu.Iu., “Ekologicheskii krizis V-VII vv. i final 'kul'tury rechnykh dolin' (na primere pogranich'ia lesa i lesostepi Dneprovskogo Levoberezh'ia)" [The ecological crisis of the fifth to seventh century and the end of the "river valley cultures" (an example from the frontier region between the forest and the steppe-forest belts in Left-Bank Ukraine)], in V.I. D'iachenko/L.R. Pavlinskaia (eds.), Priroda i civilizaciia. Reki i kul'tury. Materialy konferencii. Posviashchaetsia 1oo-letiiu vykhoda v svet pervogo russkogo izdaniia knigi vydaiushchegosia uchenogo L.I. Mechnikova "Civilizaciia $i$ velikie istoricheskie reki”, St. Petersburg 1997, pp. 213-219.

Shevchenko, Iu.Iu., Vzone slavianskogo etnogeneza. Paleodemoekologiia Nizovii Desnyv pervom tysiacheleti nashei ery [Inside the Slavic ethnogenesis zone. The paleodemoecology of the Lower Desna area during the first millennium A.D.], St. Petersburg 2002.

Sikora, J., "Akulturacja, wymuszona chrystianizacja czy migracja? Problem genezy wczesnośredniowiecznej inhumacji na Pomorzu" [Acculturation, forced Christianization or migration? The problem of the origin of inhumation in early medieval Pomerania], in W. Dzieduszycki/J. Wrzesiński (eds.), Migracje, Poznań 2013, pp. $135^{-146 .}$

Sindbæk, S.M., "A Magyar occurence. Process, practice, and ethnicity between Europe and the steppes", Acta Archaeologica 70 (1999), 149-164.

Šlaus, M., "Kraniometrijska analiza srednjovjekovnih populacija središnje Europe s posebnim osvrtom na položaj hrvatskih nalazišta" [Craniometric relationships of medieval Central European populations: implications for the ethnogenesis of the Croats], Starohrvatska prosvjeta 25 (1998), 81-107.

Šlaus, M./Tomičić, Ž./Uglešić, A./Jurić, R., "Craniometric relationships among medieval Central European populations: implications for Croat migration and expansion", Croatian Medical Journal 45/4 (2004), 434-444.

Smirnov, A.P., "Nekotorye spornye voprosy istorii volzhskikh bolgar" [Some fundamental problems of the history of the Volga Bulgars], in D.A. Avdusin/V.L. Ianin (eds.), Istoriko-arkheologicheskii sbornik. Artemiiu Vladimirovichu Arcikhovskomu shestidesiatiletiiu so dnia rozhdeniia i tridcatipiatiletiiu nauchnoi, pedagogicheskoi $i$ obshchestvennoi deiatel'nosti, Moscow 1962, pp. 160-174.

Sołtysiak, A., "The plague endemic and Slavic expansion in the 6th-8th centuries", Archaeologia Polona 44 (2006), 339-364.

Stadtmüller, G., Geschichte Südosteuropas, Munich 1950.

Stanev, K., "Migraciiata ot Trakiia kăm Severna Bălgariia v kraia na XII-nachaloto na XIII vek i neinite posledici" [The late 12th- to early 13th-century migration from Thrace to northern Bulgaria and its consequences], in G.N. Nikolov/A. Nikolov (eds.), Srednovekovniiat bălgarin i “drugite”. Sbornikv chest na 6o-godishniia na prof. d. i.n. Petăr Angelov, Sofia 2013, pp. 207-226. 
Szabados, Gy., "A legyőzött magyarok mint hódítók? A De Administrando Imperio és a népvándorlások antik modellje" [The conquered Hungarians as the conquering ones? The De administrando imperio and the ancient model of the migrations], in T. Olajos (ed.), A Kárpát-medence, a magyarság és Bizánc, Szeged 2014, pp. 259-275. Szenthe, G., "Technological history, experimental archaeology and bronze casting: research findings and research perspectives in early medieval studies", Hungarian Archaeology (2013), 1-6.

Szentpéteri, J., "Was die Verbreitungskarten erzählen... Beiträge zum Problemkreis der Datierung der Awarenzeit", Antaeus 29 (2008), 325-346.

Tăpkova-Zaimova, V., "Roliata i administrativnata organizaciia na t. nar. 'otvăddunavska Bălgariia" [The role and the administrative structure of the so-called "Bulgaria beyond the Danube"], in N. Todorov/V. Beshevliev/S. Velikov/K. Georgiev/S. Dimitrov/P. Miiatev/P. Rusev (eds.), Prouchvaniia po sluchai II Kongres po balkanistika, Sofia 1970, pp. 63-73.

Tăpkova-Zaimova, V., "Migrations frontalières en Bulgarie médiévale”, in M. Balard/A. Ducellier (eds.), Migrations et diasporas méditerranéennes (Xe-XVIe siècles). Actes du Colloque de Conques (octobre 1999), Paris 2002, pp. 125-131.

Tejral, J., "Zur Unterscheidung des vorlangobardischen und elbgermanisch-langobardischen Nachlasses", in W. Pohl/P. Erhard (eds.), Die Langobarden. Herrschaft und Identität, Vienna 2005, pp. 103-200.

Tejral, J., “K současnému stavu archeologického i historického bádání o nejčasnějším středověku na Moravě" [To the present state of archaeological and historical research on the early Middle Ages in Moravia], in J. Doležel/M. Wihoda (eds.), Mezi raným a vrcholným středověkem. Pavlu Kouřilovi k šedesátým narozeninám přátelé, kolegové a žáci, Brno 2012, pp. 29-68.

Teodor, D.Gh., "Evoluţia demografică şi culturală la est de Carpaţi în secolele v-XI d. Hr." [The demographic and cultural evolution in the lands to the east from the Carpathian Mountains between the $5^{\text {th }}$ and the 11th century], Mousaios 15 (2010), 285-310.

Tomka, P., "Die Frage der ethnischen oder kulturellen Verwandschaft bzw. interethnische Wirkung im Spiegel der Begräbnissitten”, A Wosinsky Mór Múzeum Evkönyve 15 (1990), 163-174.

Tóth, S.L., Levediától a Kárpát-medencéig. [From Lebedia to the Carpathian Basin], Szeged 1998.

Tóth, T., "Észak-dunántul avarkori népességének embertani problémái" [Anthropological problems fo the Avar population in northern Transdanubia], Arrabona 9 (1967), 55-65.

Trugly, A., "Komárom-Hajógyár avar nemesi temetője” [The elite cemetery excavated in Komárno-Lodenica], in A.K. Molnár/A. Nagy/P. Tomka (eds.), Jöttek-mentek. Langobardok és avarok a Kisalföldön. Kiállításvezetö, Győr 2008, pp. 199-216. 
Türk, A., "O novykh rezul'tatakh issledovaniia katakombnykh pogrebenii(Stollengräber) v Karpatskom basseine" [New results in the study of graves with tunnel-shaped shafts in the Carpathian Basin], in R.D. Goldina/I.G.Shapran/N.A.Leshchinskaia/L.D. Makarov (eds.), Vzaimodeistvie narodov Evrazii v epokhu velikogo pereseleniia narodov, Izhevsk 2006, pp. 180-184.

Turkina, T.Iu., "Poselenie Bichevnik I na srednei Pechore (po materialam raskopok 2013 g.)" [The Bichevnik I settlement on the Middle Pechora (on materials of the $2013 \mathrm{ex}-$ cavations)], Materialy po arkheologii evropeiskogo Severo-Vostoka 19 (2015), 80-88.

Tütken, Th./Knipper, C./Alt, K.W., "Mobilität und Migration im archäologischen Kontext: Informationspotential von Multi-Element-Isotopenanalysen ( $\mathrm{Sr}, \mathrm{Pb}, \mathrm{O})$ ), in J. Bemmann/M. Schmauder (eds.), Kulturwandel im Mitteleuropa. LangobardenAwaren-Slawen. Akten der internationalen Tagung in Bonn vom 25. bis 28. Februar 2008, Bonn 2009, pp. 13-42.

Tvauri, A., "Migrants or natives? The research history of long barrows in Russia and

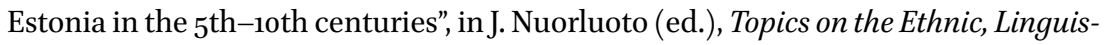
tic and Cultural Making of the Russian North, Helsinki 2007, pp. 1-38.

Udolph, J., "Die Landnahme der Ostslaven im Lichte der Namenforschung”, Jahrbücher für Geschichte Osteuropas 29 (1981), 322-336.

Urbańczyk, P., "Obcy wśród Słowian”. [The role of foreign leaders in early Slavic societies], in M. Miśkiewiczowa (ed.), Stowianie w Europie wczesniejszego średniowiecza. Katalog wystawy, Warsaw 1998, pp. 65-77.

Urbańczyk, P., "Foreign leaders in early Slavic societies", in W. Pohl/M. Diesenberger (eds.), Integration und Herrschaft. Ethnische Identitäten und soziale Organisation im Frühmittelalter, Vienna 2002, pp. 257-268.

Váczy, P., "The Byzantine emperor Constantine VII Porphyrogenitus and the saga of the Hungarian conquest", Antaeus 19-20 (1990), 251-256.

Vajda, L. "Zur Frage der Völkerwanderungen”, Paideuma 19-20 (1973-1974), 5-53.

Vavruš, J., "Prvá mad'arská generácia v archeologických a písomných prameňoch" [The first generation of Magyars in the archaeological and written sources], in T. Štefanovičová/D. Hulínek (eds.), Bitka pri Bratislave v roku goz a jej význam pre vývoj stredného Podunajska. Kolokvium sa uskutočnilo v Bratislave 19-20. júna 2007, Bratislava 2008, pp. 183-193.

Viazov, L.A., "Proiskhozhdenie pakhotnykh orudii imen'kovskoi kul'tury" [The origin of the agricultural tools in the Imen'kovo culture], in A.A. Vybornov/N.N. Kovaliuk/V.V. Skripkin/N.S. Berezina/A.V. Viskalin/V.V. Stavickii (eds.), Aktual'nye voprosy arkheologii Urala i Povolzh'ia. Sbornik statei, Samara 2008, pp. 320-342.

Viazov, L.A., "O proiskhozhdenii toporov imen'kovskoi kul'tury" [On the origin of the axes in the Imen'kovo culture], in D.A. Stashenkov (ed.), Aktual'nye voprosy arkheologii Povolzh'ia. K 65-letiiu studencheskogo nauchnogo arkheologicheskogo kruzhka Kazanskogo universiteta, Kazan' 2012, pp. 43-53. 
Viazov, L.A./Stashenkov, D.A., “Kul'turno-khronologicheskie gruppy naseleniia Samarskogo i Ul'ianovskogo Povolzh'ia v epokhu Velikogo pereseleniia narodov" [Cultural and chronological groups of the population in the Samara and Ul'ianovsk region of the Volga during the Migration period], in E.V. Goldina/N.A. Leshchinskaia/E.M. Chernykh/I.G.Shapran(eds.),Istoriko-kul'turnoenasledie-resursformirovaniiasocial'noistoricheskoi pamiati grazhdanskogo obshchestva (XIV Baderovskie chteniia). 14-15 oktiabria, g. Izhevsk, Izhevsk 2013, pp. 49-56.

Vida, T., "Aufgaben und Perspektiven der Langobardenforschung in Ungarn nach István Bóna", in J. Bemmann/M. Schmauder (eds.), Kulturwandel in Mitteleuropa. Langobarden-Awaren-Slawen; Akten der Internationalen Tagung in Bonn vom 25. bis 28. Februar 20o8, Bonn 2008, pp. 343-362.

Vida, T., "Die Langobarden in Pannonien”, in M. Hegewisch (ed.), Die Langobarden. Das Ende der Völkerwanderungszeit. Katalog zur Ausstellung im Rheinischen Landesmuseum Bonn, 22.8.2008-11.1.2009, Bonn/Darmstadt 2008, pp. 73-89.

Vida, T., "La ricerca e le ultime scoperte longobarde in Pannonia: una sintesi", in E. Possenti (ed.), Necropoli longobarde in Italia. Indirizzi della ricerca e nuovi dati, Castello del Buonconsiglio 2014, pp. 55-72.

Volkov, V.G., "K voprosu o migraciiakh i prarodine kychapkov. Geneticheskii aspekt", [On the question of the migrations and homeland of the Cumans. Genetic aspects] Zolotoordynskaia civilizaciia 9 (2016), 298-308.

Werner, J., Der Schatzfund von Vrap in Albanien. Beiträge zur Archäologie der Awarenzeit im mittleren Donauraum, Vienna 1986.

Werner, J., "Der Schatz eines awarischen Kagans des 7. Jahrhunderts aus Vrap (Albanien)", Problemi na prabălgarskata istoriia i kultura 1 (1989), 19-31.

Zahra, T., The Great Departure. Mass Migration from Eastern Europe and the Making of the Free World, New York 2016.

Zav'ialov, V.I./Terekhova, N.N., "Three-fold welding technology in the blacksmith's craft of medieval Rus' (concerning Scandinavian innovations)", in A. Hauptmann/D. Moraressi-Tehrani (eds.), Archaeometallurgy in Europe III. Proceedings of the 3 rd International Conference, Deutsches Bergbau-Museum, Bochum, June 29-July 1, 2011, Bochum 2015, pp. 247-254.

Zimonyi, I., "A besenyők nyugatra vándorlásának okai” [On the westward migration of the Pechenegs], Acta Universitatis Szegediensis de Attila Jozsef nominatae. Acta Historica 106 (1998), 129-144.

Živković, T., De conversione Croatorum et Serborum. A Lost Source, Belgrade 2012. 